\title{
1 Anaerobic Soil Disinfestation Impact on Soil Nutrients Dynamics and Nitrous Oxide Emissions in
}

\section{Fresh-market Tomato}

3 Francesco Di Gioia ${ }^{1 *}$, Monica Ozores-Hampton ${ }^{1}$, Xin Zhao ${ }^{2}$, John Thomas ${ }^{3}$, Patrick Wilson ${ }^{3}$, Zhuona Li $^{3}$,

4 Jason Hong ${ }^{4}$, Joseph Albano ${ }^{4}$, Marilyn Swisher ${ }^{5}$, and Erin Rosskopf ${ }^{4}$

$6{ }^{1}$ South West Florida Research and Education Center, Institute of Food and Agricultural Sciences,

7 University of Florida, State Road 29 N, Immokalee, FL 34142

$8 \quad{ }^{2}$ Horticultural Sciences Department, University of Florida, 1301 Fifield Hall, Gainesville, FL 32611

$9 \quad{ }^{3}$ Soil and Water Science Department, University of Florida, 1692 McCarty Dr, Gainesville, FL 32603

$10{ }^{4}$ USDA, ARS, United States Horticultural Research Laboratory, 2001 S. Rock Road, Fort Pierce, FL

1134945

$12{ }^{5}$ Sustainable Agriculture, Family, Youth and Community Sciences, University of Florida, Gainesville, FL $13 \quad 32611$

14

$15{ }^{*}$ Corresponding author. Email address: fdigioia@ufl.edu Telephone: +1 7724625828 
17 Anaerobic soil disinfestation (ASD) is proposed as a pre-plant, non-chemical soil disinfestation technique

18 to control several soilborne phytosanitary issues. Limited information is available on the impact of ASD

19 on soil fertility, plant growth, and potential nutrient loss. The objectives of the current study were to

20 evaluate the effects of ASD applied using composted poultry litter (CPL) and molasses as amendments,

21 on soil redox potential, $\mathrm{pH}$, temperature, soil nutrient content, plant biomass and nutrient accumulation,

22 and nitrous oxide $\left(\mathrm{N}_{2} \mathrm{O}\right)$ emissions. A field study was conducted on fresh-market tomato (Solanum

23 lycopersicum L.) at two sites, Immokalee and Citra, FL, comparing ASD applied using a mix of CPL at

24 the rate of $22 \mathrm{Mg} \mathrm{ha}^{-1}$ and two rates of molasses [13.9 (ASD1) and $27.7 \mathrm{~m}^{3} \mathrm{ha}^{-1}$ (ASD2)] as a carbon-

25 source to chemical soil fumigation (CSF). ASD treatment had a significant impact on soil redox potential,

26 but did not affect soil $\mathrm{pH}$ or temperature. Soil treatment did not affect nitrous oxide emissions from intact

27 polyethylene mulched beds at either location. Emissions ranged from 0 to $0.378 \mu \mathrm{g} \mathrm{m}^{-2} \mathrm{~h}^{-1}$ and from 8.8 to

$2839.8 \mu \mathrm{g} \mathrm{m}^{-2} \mathrm{~h}^{-1}$ in Immokalee and Citra, respectively. However, on day 21 after punching holes in the

29 polyethylene film to transplant, $\mathrm{N}_{2} \mathrm{O}$ emissions ranged from 1.56 to 4.83 and from 303.4 to $1480.1 \mu \mathrm{g} \mathrm{m}^{-2}$

$30 \mathrm{~h}^{-1}$ in Immokalee and Citra, respectively. Emissions were higher in ASD than in CSF plots in Citra, but

31 not in Immokalee. Molasses and CPL used in ASD treatments increased soil nutrients content, and

32 particularly the availability of $\mathrm{P}$ and $\mathrm{K}$. Results show no clear evidence of an increased risk of $\mathrm{N}$ loss with

33 ASD compared to CSF. However, pre- and post-planting nutrient management should be adjusted to take

34 into account the nutrients provided through the molasses and CLP application.

36 Keywords: biological soil disinfestation, molasses, composted poultry litter, nitrous oxide, phosphorous,

37 potassium, chemical soil fumigation 


\section{Introduction}

43 Anaerobic soil disinfestation (ASD) is a pre-plant non-chemical soil disinfestation treatment proposed as

44 an alternative to chemical soil fumigation (CSF) for the control of several soil-borne diseases, plant-

45 parasitic nematodes, and weeds in a variety of crops (Rosskopf et al., 2015; Shennan et al., 2014;

46 Shinmura et al., 1999). The basic principle of the technique, known also as 'biological soil disinfestation',

47 is to create an anaerobic soil environment by incorporating readily decomposable carbon (C) rich organic

48 amendments into the soil, which is saturated with water and covered with impermeable polyethylene film

49 to prevent the diffusion of oxygen from the soil surface (Butler et al., 2014a; Shennan et al., 2014). The

50 temporary shift of the soil environment, from aerobic to anaerobic conditions, that occurs for a few days,

51 stimulates the growth of facultative and obligate anaerobic microorganisms, including Clostridia and

52 Bacilli groups (Mowlick et al., 2012, 2013a, 2013b; van Agtmaal et al., 2015). Under anaerobic

53 conditions, these microorganisms decompose the labile C, producing organic acids, aldehydes, alcohols,

54 ammonia, and volatile organic compounds that are suppressive or toxic for several soil-borne pests and

55 plant pathogens (Momma, 2008; Momma et al., 2006; Oka, 2010; van Agtmaal et al., 2015).

56 While the exact mechanism of pest control has not been fully elucidated, the ASD technique proved to be

57 effective against a number of soilborne pests (Butler et al., 2012a, 2012b; Lamers et al., 2010; Momma,

58 2008; Rosskopf et al., 2015; Shennan et al., 2014). Besides soil pest control, the transient variation of soil

59 redox potential, $\mathrm{pH}$, and microbial populations caused by the ASD treatment (Momma, 2008; Momma et

60 al., 2006), combined with amendment of the soil with organic matter, may have a significant impact on

61 soil nutrient content and dynamics, plant nutritional status and growth, as well as on the loss of nutrients

62 to the environment (Rosskopf et al., 2015). In previous studies, ASD applied on different vegetable crops,

63 increased soil nutrient content, improved plant growth, and provided higher fruit yield compared to the

64 fumigated control (Butler et al. 2014a; Di Gioia et al., 2016). Nevertheless, information on the potential

65 environmental impact of the ASD technique is inadequate and there are concerns about the potential risks

66 of nutrient loss, especially during the treatment period prior to transplanting. It is possible that nutrients,

67 particularly inorganic N, may be immobilized into the soil microbial biomass or may be subject to losses, 
68 principally through leaching out of the root zone (Benoit et al., 2015). As anaerobic conditions are created

69 during the ASD treatment, $\mathrm{N}$ losses may occur by denitrification with the reduction of nitrate $\left(\mathrm{NO}_{3}{ }^{-}\right)$to

70 gaseous forms of $\mathrm{N}$, including $\mathrm{N}_{2}$ and $\mathrm{N}_{2} \mathrm{O}$, which is a potent greenhouse gas currently considered the

71 most important substance contributing to stratospheric ozone depletion (Charles et al., 2017;

72 Ravishankara et al., 2009).

73 A field study was conducted on fresh-market tomato grown in open-field in two locations in Florida to

74 examine the potential implications of ASD for both the soil-plant system and the environment. The

75 objectives were to evaluate the effects of ASD and the most common CSF practices on soil temperature,

76 moisture, $\mathrm{pH}$, redox potential, nutrient content, and soil $\mathrm{N}_{2} \mathrm{O}$ emissions; to evaluate effects on plant

77 growth and nutrient accumulation, and estimate the residual fertility and the potential risk of nutrient loss

78 at the end of the crop season.

\section{Materials and Methods}

\subsection{Experimental sites and treatments}

82 Two field experiments were conducted on fresh-market tomato during the spring season of 2015 in

83 southwestern (Immokalee) and north-central Florida (Citra). Conventional CSF was compared with two

84 ASD treatments, which consisted of amending the soil with $22 \mathrm{Mg} \mathrm{ha}^{-1}$ of CPL and two rates of molasses

85 [13.9 (ASD1) and $27.7 \mathrm{~m}^{3} \mathrm{ha}^{-1}$ (ASD2)] as the C source. The first experiment was established on 2 Feb.

862015 at the University of Florida (UF) - Institute of Food and Agriculture Sciences - Southwest Florida

87 Research and Education Center (SWFREC) in Immokalee, FL. The second experiment was established on

8825 Mar. 2015, at the UF Plant Science Research and Education Unit (PSREU). Weather conditions and

89 treatment effects on fruit yield and quality, weed and root-knot nematode control, and cumulative soil

90 anaerobicity ( $\mathrm{mV} \mathrm{hr)} \mathrm{were} \mathrm{reported} \mathrm{previously} \mathrm{by} \mathrm{Di} \mathrm{Gioia} \mathrm{et} \mathrm{al.} \mathrm{(2016).}$

91 The three treatments, CSF, ASD1 and ASD2, were the same at both sites and were arranged in a

92 randomized complete block design with four replications. The two sites differed in soil type. In

93 Immokalee, the soil was a Spodosol classified as Immokalee fine sand (sandy, siliceous, hyperthermic 
94 Arenic Haplaquods) and in Citra the soil was a Gainesville loamy sand (hyperthermic, coated typic

95 quartzipsamments). In addition, there were minor differences in the way beds were established. In

96 Immokalee, each of the four blocks consisted of one raised bed, $0.90 \mathrm{~m}$ wide, $0.20 \mathrm{~m}$ high and $60 \mathrm{~m}$ long

97 and treatments were applied to $15-\mathrm{m}$ long sections of the bed, leaving a 3-m space between plots. In Citra,

98 each of the four blocks consisted of three beds $0.90 \mathrm{~m}$ wide and $15-\mathrm{m}$ long. Prior to treatment application,

99 the soil was rototilled and a starter fertilizer mix including N, P and potassium (K) was applied based on

100 the specific requirement of each site. Nitrogen, $\mathrm{P}$ and $\mathrm{K}$ were applied at the rate of 34,49 and $37 \mathrm{~kg} \mathrm{ha}^{-1}$ at

101 the Immokalee site, and 56, 22 and $42 \mathrm{~kg} \mathrm{ha}^{-1}$ in Citra, respectively. The starter fertilizer mix was

102 broadcast applied to the soil surface in $60 \mathrm{~cm}$ wide bands at both sites. Rounded false beds were formed

103 by hilling the soil from a depth of $10 \mathrm{~cm}$. ASD beds were amended with CPL at the rate of $22 \mathrm{Mg} \mathrm{ha}^{-1}$ in

104 combination with a 1:1 (v:v) water dilution of sugarcane molasses (Agricultural Carbon Source,

105 TerraFeed, LLC, Plant City, FL, USA). Molasses had a density of $1,420 \mathrm{~kg} \mathrm{~m}^{-3}, 22 \%$ water content, and a

$106 \mathrm{pH}$ of 4.9-5.2. The molasses-water mix was applied to ASD1 and ASD2 plots at the rate of 27.7 and 55.4

$107 \mathrm{~m}^{3} \mathrm{ha}^{-1}$. Table 1 shows the mean macro- and micro-nutrient content of both CPL and molasses, and the

108 total amounts of nutrients incorporated in the soil with the ASD1 and ASD2 treatment application.

109 After CPL and molasses application, the soil was tilled to a depth of $15 \mathrm{~cm}$ with a rotary cultivator, beds

110 were formed and covered with a 0.03-mm black/white VaporSafe ${ }^{\circ}$ TIF (Raven Industries Inc., Sioux

111 Falls, SD, USA) polyethylene mulch containing an ethylene vinyl alcohol (EVOH) barrier layer.

112 Simultaneously, two drip irrigation lines [20 cm emitter spacing, $0.98 \mathrm{~L} \mathrm{~h}^{-1}$ emitter rate (Jain Irrigation

113 Inc., Haines City, FL, USA)] were installed under the mulch in each bed, approximately $2.54 \mathrm{~cm}$ below

114 the soil surface and $20 \mathrm{~cm}$ apart from the center of the bed. ASD plots were then irrigated with $5 \mathrm{~cm}$ of

115 water (based on raised-bed area only) to saturate air-filled pore space in the top $10 \mathrm{~cm}$ of the bed and

116 enhance the development of anaerobic conditions (Butler et al., 2012).

117 On the same day, the control plots were fumigated by shank injection. The fumigant applied at each

118 location was the most commonly used product for vegetable production in that region. In Immokalee,

119 fumigation was with Pic-Clor 60 (Soil Chemical Corporation, Hollister, CA, USA) containing a mixture 
120 of 1,3-dichloropropene (39.0\%) and chloropicrin (59.6\%) at the rate of $224 \mathrm{~kg} \mathrm{ha}^{-1}$. In Citra, the fumigant

121 was Paladin ${ }^{\mathrm{TM}}$ (Arkema Inc., King of Prussia, PA, USA) composed of dimethyl-disulfide (DMDS, 79\%)

122 and chloropicrin $(21 \%)$ at the rate of $496 \mathrm{~L} \mathrm{ha}^{-1}$. Fumigated plots were mulched immediately following

123 CSF injection at both sites using the same material as for the ASD plots.

124 2.2. Crop transplanting and growing conditions

125 Tomato varieties were selected based on regional grower preferences. The varieties were cv. 'Skyway

126 687' (Enza Zaden, Salinas, CA, USA) in Immokalee and cv. 'Tribute' (Sakata, Morgan Hill, CA, USA) in

127 Citra. Both are large, round fresh-market commercial tomato varieties. They were transplanted at the third

128 true leaf stage, three weeks after treatment application, 24 Feb. and 17 Apr. 2015 in Immokalee and Citra,

129 respectively. Tomatoes were transplanted in single rows at a distance of $0.45 \mathrm{~m}$ within the row and $1.8 \mathrm{~m}$

130 between rows, establishing a density of 12,000 plants $\mathrm{ha}^{-1}$ at each site. Each of the twelve plots in the

131 experiment contained 34 plants. Plants were trellised using the stake and weave method at both sites.

132 Irrigation and fertigation differed by site. A hybrid seepage-drip irrigation system was used in Immokalee,

133 while in Citra, the crop was watered by drip irrigation as described by Di Gioia et al. (2016). Fertigation

134 started three weeks after planting (WAP) following UF/IFAS fertilizer recommendations (FDACS, 2005).

135 At the Immokalee site, $\mathrm{N}$ and $\mathrm{K}$ were applied twice a week by fertigation using potassium nitrate (13-0-

136 44) and ammonium nitrate (34-0-0). In Citra, fertilizer was applied by fertigation once per week using a

137 6-0-8 plus micro blend by Mayo Fertilizer Inc. (Mayo, FL, USA). Total season fertilizer rates applied by

138 fertigation were 180 and $268 \mathrm{~kg} \mathrm{ha}^{-1}$ of $\mathrm{N}$ and 263 and $265 \mathrm{~kg} \mathrm{ha}^{-1}$ of $\mathrm{K}$ in Immokalee and Citra,

139 respectively. Total season N, P and K fertilizer rates were 214, 49 and $300 \mathrm{~kg} \mathrm{ha}^{-1}$ in Immokalee, and 323,

14022 and $307 \mathrm{~kg} \mathrm{ha}^{-1}$ in Citra, respectively. The quantity of nutrients applied with the starter fertilizer mix

141 and by fertigation was not adjusted between treatments considering the amount of nutrient applied with

142 the organic amendment in the ASD plots (Table 1), because it was assumed that only a portion of the

143 latter would be available to the plants during the crop cycle. Moreover, given the potential effects of the

144 temporary change of the soil redox potential and $\mathrm{pH}$ on the soil microbiome and microbial activity,

145 limited information is available to estimate the potential mineralization rates of the organic material 
146 incorporated in the soil in ASD plots. In addition, many growers will not abandon their standard practice

147 of a broadcast application of slow-release fertilizer when adopting ASD, therefore this approach allowed

148 an assessment of the "worst case scenario" for nutrient loss (Ozores-Hampton et al., 2015).

\subsection{Soil temperature, moisture and redox potential}

150 Soil temperature and volumetric water content were monitored during the three-week treatment period.

151 Temperature sensors and soil moisture probes were installed before initial irrigation at both sites. Two 12-

152 Bit temperature smart sensors (S-TMB-M006, Onset Computer Corporation, Pocasset, MA, USA) were

153 installed at 5 and at $10 \mathrm{~cm}$ depths and two ECH2O ${ }^{\circledR}$ Dielectric Acquameter probes (EC-5, Decagon

154 Devices Inc., Pullman, WA, USA) were installed at $10 \mathrm{~cm}$ depth in each plot. Both soil temperature and

155 soil moisture probes were connected to an automatic data logging system (Onset Computer Corporation,

156 Pocasset, MA, USA). Two oxidation-reduction potential sensors (Pt combination electrodes, $\mathrm{Ag} / \mathrm{AgCl}$

157 reference, Sensorex, Garden Grove, CA, USA) were also installed before initial irrigation at $15 \mathrm{~cm}$ depth.

158 These sensors were used to evaluate the occurrence of anaerobic soil conditions (indicated by redox

159 potential; Eh) and to monitor the degree of anaerobiosis achieved in the soil during the first three weeks

160 after treatment application. Electrodes were continuously monitored using an automatic data logging

161 system (CR-1000 with AM 16/32 multiplexers, Campbell Scientific, Logan, UT, USA).

162 2.4. Surface air sampling and $\mathrm{N}_{2} \mathrm{O}$ analysis

163 Nitrous oxide gas emissions were monitored from the top of the sealed, mulched beds 1, 2, and 3 or 4

164 days after treatment application, and at transplanting (21 days after treatment application), while punching

165 holes in the polyethylene bed mulch. Emissions were collected using custom made static chambers made

166 from 4.7 L stainless steel bowls. The bowls were placed on top of the polyethylene mulched bed in

167 randomly selected positions and were sealed with grease. Each stainless steel bowl had a hole at the top of

168 the head space on which was mounted a $9.5 \mathrm{~mm}$ silicone/PTFE septum (Alltech Microsep F-174N) by

169 means of a stainless steel bulkhead union sealed with epoxy cement. Gas samples were collected at

170 intervals of 15 minutes for 60 minutes at each monitoring time. Through the silicon septum of each static

171 chamber, $10 \mathrm{~mL}$ of surface air were withdrawn using a gas tight plastic syringe attached to a 10 -cm long 
172 metal needle by means of a 3-4 cm Masterflex silicone rubber tube. Air samples collected were trapped in

173 non-coated $10 \mathrm{~mL}$ Vacutainer® sampling tubes (BD Diagnostics, Franklin Lakes, NJ, USA). Tubes were

174 stored in a cooler with ice immediately after taking the sample and then transferred to a freezer $\left(-20^{\circ} \mathrm{C}\right)$

175 in the laboratory until processing for analysis.

176 Nitrous oxide concentrations in the samples were measured by gas chromatography (GC) using a Perkin-

177 Elmer Clarus 400 GC equipped with an electron capture detector (ECD) and a 80/100 Porapak Q stainless

178 steel column measuring $1.8 \mathrm{~m}$ (length) $\times 3.18 \mathrm{~mm}(\mathrm{OD}) \times 2.1 \mathrm{~mm}$ (ID) (Supelco catalog \# 12437). The

179 carrier gas was UHP helium held at 10 psi. Samples were manually injected using a 250 or $500 \mu \mathrm{L}$

180 Pressure-Lok gas syringe (Dynatech Precision Sampling Corp, Baton Rouge, LA, USA) into an unpacked

181 injector held at $60^{\circ} \mathrm{C}$. The GC was operated in split/splitless mode where the split vent was open at 0.3

182 minutes and closed at 4.0 minutes. The GC oven was maintained at $35{ }^{\circ} \mathrm{C}$ and the ECD at $350{ }^{\circ} \mathrm{C}$.

183 Calibration used external standard concentrations ranging from 2.1 to $42.9 \mu \mathrm{Mol} \mathrm{N}_{2} \mathrm{O}$. Standard

184 concentrations were made by injection of appropriate volumes of a $\mathrm{N}_{2} \mathrm{O}$ standard gas $(9.98$ ppm certified

$185 \mathrm{~N}_{2} \mathrm{O}$ in Helium at 1.04 atm pressure; Air Liquide catalog \# T445-221) into the GC. Temperature and

186 pressure corrections were accounted for using the Ideal Gas Law and Dalton's Law for partial pressures.

187 Under conditions stated above the minimum detection limit (MDL) was $0.0017 \mu \mathrm{Mol} \mathrm{N}_{2} \mathrm{O}$ at a $95 \%$

188 confidence level (Hubaux, 1970). A storage study using vacutainer vials with a known concentration of

$189 \mathrm{~N}_{2} \mathrm{O}$ kept at $4{ }^{\circ} \mathrm{C}$ in a refrigerator revealed less than $5 \%$ degradation in 35 days. All samples in the storage

190 study and field study were warmed to ambient temperatures prior to injection.

$191 \quad$ 2.5. Soil and soil solution sampling and nutrient analyses

192 Prior to treatment application, six soil cores $(1.75-\mathrm{cm}$ internal diameter) were taken randomly from each

193 plot, excluding plot borders, at both sites at 30-cm depth. The six cores were combined in a single bulk

194 sample for each plot. The same procedures were used for soil sampling at three weeks after treatment

195 application (right before planting) and at the end of the crop season, 92 and 95 days after planting in

196 Immokalee and Citra, respectively. Soil pH was measured directly in each moist soil sample using a

197 FieldScout SoilStik pH meter (Spectrum Technologies, Inc, Aurora, IL, USA). Soil samples were air- 
dried and then sieved $(<2 \mathrm{~mm})$. Samples were analyzed to determine the concentration of the N, C, P, K,

199 calcium $(\mathrm{Ca})$, magnesium $(\mathrm{Mg})$, sodium $(\mathrm{Na})$, iron $(\mathrm{Fe})$, boron $(\mathrm{B})$, copper $(\mathrm{Cu})$, zinc $(\mathrm{Zn})$, manganese

200 (Mn), molybdenum (Mo) and nickel (Ni). Total N and C content were determined by combustion (NC

201 Soil Flash EA1112, CE Elantech Inc., Lakewod, NJ, USA). Dry soil samples were digested utilizing a

202 closed-vessel microwave-assisted digestion (MARS Express, CEM Corp., Matthews, NC, USA)

203 according to U.S. EPA method 3052 (USEPA, 1997). Digested products were then analyzed by

204 inductively coupled plasma atomic emissions spectrometry (ICP-AES; iCAP 6500, Thermo Scientific,

205 Waltham, MA, USA) to determine the concentrations of $\mathrm{P}, \mathrm{K}, \mathrm{Ca}, \mathrm{Mg}, \mathrm{Fe}, \mathrm{B}, \mathrm{Cu}, \mathrm{Zn}, \mathrm{Mn}, \mathrm{Na}$, Mo and

206 Ni.

207 A soil solution suction sampler (model SSAT, Irrometer Company Inc., Riverside, CA, USA) was

208 installed to a depth of $30 \mathrm{~cm}$ in the center of each experimental plot prior to initial irrigation. Two

209 subsamples of soil solution were collected from each suction sampler by applying vacuum (-70 kPa) for

21024 hours at 7, 14 and 21 days after treatment application. Soil solution samples collected in $20 \mathrm{~mL}$ plastic

211 vials were transported from the field in an ice chest and then stored in a freezer $\left(-20^{\circ} \mathrm{C}\right)$ pending chemical

212 analyses. Soil solution samples were analyzed by inductively coupled plasma atomic emissions

213 spectrometry (ICP-AES; iCAP 6500, Thermo Scientific, Waltham, MA, USA) to determine the

214 concentrations of $\mathrm{P}, \mathrm{K}, \mathrm{Ca}, \mathrm{Mg}, \mathrm{Fe}, \mathrm{B}, \mathrm{Cu}, \mathrm{Zn}, \mathrm{Mn}, \mathrm{Na}, \mathrm{Zn}$, and Ni. The soil solution $\mathrm{NO}_{3}{ }^{-}$concentration

215 was determined by ion chromatography, using an ICS 1000 (Dionex Corporation, Sunnyvale, CA, USA)

216 with a conductivity detector with an IonPack AG14 pre-column and an IonPac AS14 separation column

217 operating at $1800-1900$ psi. The detector and suppressor were set at $17 \mathrm{mS}$ and 24 miliamps,

218 respectively. The eluent consisted of $20 \mathrm{~mL}$ of $3.5 \mathrm{mmol} \mathrm{L}^{-1}$ of sodium carbonate and $1.0 \mathrm{mmol} \mathrm{L}^{-1}$ of

219 sodium bicarbonate solution. A $25 \mu \mathrm{L}$ sample loop was used, and $5 \mathrm{~mL}$ samples were injected. Quality

220 control standards and distilled-deionized water method blanks were used to ensure that the ion

221 chromatography system was operating properly.

222 2.6. Plant growth and nutrient accumulation analysis 
223 Plant growth was measured at 57 and 91 days after planting in Immokalee and Citra, respectively. Two

224 representative plants were sampled from each plot and the fresh weight of leaves, stems, and fruit were

225 measured and recorded for each plant. Plant material was dried to constant weight in a forced-air oven at

$22665^{\circ} \mathrm{C}$ to determine the dry weight (DW). Dried leaf, stem, and fruit samples were finely ground through a

227 mill to pass through a 20 -mesh screen and $0.5 \mathrm{~g}$ of the dried plant tissues were analyzed to determine

228 content of N, P, K, Ca, Mg, Fe, B, Cu, Zn, Mn, Na, Zn, and Ni. Total N content was determined by

229 combustion (NC Soil Flash EA1112, CE Elantech Inc., Lakewod, NJ, USA). Dry plant samples were

230 digested utilizing a closed-vessel microwave-assisted digestion (MARS Express, CEM Corp., Matthews,

231 North Carolina, USA) according to U.S. EPA method 3052 (USEPA 1997). Digested products were then

232 analyzed by inductively coupled plasma atomic emissions spectrometry (ICP-AES; iCAP 6500, Thermo

233 Scientific, Waltham, MA, USA) to determine the concentrations of $\mathrm{P}, \mathrm{K}, \mathrm{Ca}, \mathrm{Mg}, \mathrm{Fe}, \mathrm{B}, \mathrm{Cu}, \mathrm{Zn}, \mathrm{Mn}, \mathrm{Na}$, 234 Zn, and Ni.

\section{$235 \quad$ 2.7. Statistical analysis}

236 Direct comparison of results between the two sites was not an objective of this study and therefore data

237 from the two locations were analyzed separately. Data were subject to analysis of variance (ANOVA)

238 using the GLM procedure in SAS Version 9.4 software (SAS Institute, Cary, NC, USA) following the

239 randomized complete block design. All means were separated using Duncan's multiple range test at $\alpha=$

240 0.05. Soil solution nutrient concentration and $\mathrm{N}_{2} \mathrm{O}$ data were analyzed using a repeated measures design

241 according to Littell et al. (1998).

245 Treatment during the three-week treatment period did not influence soil temperature at either location,

246 although overall lower soil temperatures prevailed at Immokalee than at Citra during the three weeks after

247 treatment applications (Fig. 1). In Immokalee, mean daily soil temperatures were on average 19.9 and

$24820.2^{\circ} \mathrm{C}$ at 5 and $10 \mathrm{~cm}$ depth, respectively. Daily minimum temperatures ranged from 8.8 to $18.9^{\circ} \mathrm{C}$ at 5 
cm depth and from 7.6 to $19.3{ }^{\circ} \mathrm{C}$ at $10 \mathrm{~cm}$ depth. Maximum soil temperatures ranged from 20.7 to 40.0

$250{ }^{\circ} \mathrm{C}$ at $5 \mathrm{~cm}$ depth and from 21.0 to $39.2{ }^{\circ} \mathrm{C}$ at $10 \mathrm{~cm}$ depth. In Citra, mean daily soil temperature averaged 25129.5 and $28.7^{\circ} \mathrm{C}$ at 5 and $10 \mathrm{~cm}$ depth, respectively. Daily minimum temperatures extended from 17.9 to $25228.0^{\circ} \mathrm{C}$ at $5 \mathrm{~cm}$ depth and from 15.7 to $27.7^{\circ} \mathrm{C}$ at $10 \mathrm{~cm}$ depth. Maximum soil temperature ranged from 25329.3 to $45.5^{\circ} \mathrm{C}$ at $5 \mathrm{~cm}$ and from 27.3 to $42.5^{\circ} \mathrm{C}$ at $10 \mathrm{~cm}$ depth.

254 Given that only ASD plots received $5 \mathrm{~cm}$ of initial irrigation, the volumetric soil water content during the 255 three weeks after treatment application was higher in ASD than CSF plots at both locations (Fig. 2). In 256 Immokalee, the average soil water content was $0.21,0.25$, and $0.26 \mathrm{~m}^{3} \mathrm{~m}^{-3}$ in CSF, ASD1, and ASD2 257 plots, respectively. Similarly, in Citra, the average soil water content was $0.18,0.29$, and $0.33 \mathrm{~m}^{3} \mathrm{~m}^{-3}$ in

258 CSF, ASD1, and ASD2 plots, respectively.

259 Soil $\mathrm{pH}$ was similar in both locations prior to treatment application, on average 6.5 and 6.0 in Immokalee

260 and Citra, respectively. Soil disinfestation treatment did not influence soil $\mathrm{pH}$ at three weeks after

261 treatment application and soil $\mathrm{pH}$ was on average 7.1 in both locations at that point. Nor did soil

262 disinfestation treatments affect soil $\mathrm{pH}$ at the end of the crop cycle, which averaged 6.3 in Immokalee and 2636.0 in Citra.

264 Di Gioia et al. (2016) reported the significant effect of treatments on the cumulative $\mathrm{mV}$ hr under 265 anaerobic conditions at both sites. ASD plots had significantly higher cumulative $\mathrm{mV}$ hr under anaerobic 266 conditions as compared to CSF plots that maintained aerobic conditions. The soil environment is 267 considered anaerobic when the redox potential is approximately below $+200 \mathrm{mV}$, although the critical 268 redox potential is slightly influenced by soil $\mathrm{pH}$. Response to treatment was similar at both sites (Fig. 3). 269 In Immokalee, negative Eh values were recorded in both ASD1 and ASD2 plots 30 hours after treatment 270 application and lasted for approximately 60 hours in ASD1 plots and 350 hours in ASD2 plots. The CSF 271 plots remained aerobic during the entire three-week treatment period. In Citra, negative Eh values were 272 also recorded in both ASD1 and ASD2 plots 15 hours after treatment application and lasted for 273 approximately 130 hours in ASD1 plots and 465 hours in ASD2 plots. Slightly anaerobic conditions were 
274 observed in CSF plots in Citra, but Eh values remained positive during the entire three-week treatment

275 period.

3.2. Plant growth and nutrient accumulation

277 Soil disinfestation treatments had no significant effect on plant fresh and dry weight at either location, nor

278 did treatments affect plant macro or micro nutrient partitioning (Table 2). However, soil treatments did

279 have a significant effect on plant aboveground nutrient accumulation at both sites, with plants grown in

280 ASD plots, whether at the ASD1 rate of $13.9 \mathrm{~m}^{3} \mathrm{ha}^{-1}$ molasses or at the ASD2 rate of $27.7 \mathrm{~m}^{3} \mathrm{ha}^{-1}$,

281 exhibiting higher total accumulation of most nutrients than plants grown in CSF plots.

282 Differences between treatments were more prevalent at the Immokalee site (Table 3) than the Citra site

283 (Table 4). In Immokalee, plants grown in both ASD1 and ASD2 plots had significantly higher

284 accumulations of $\mathrm{K}, \mathrm{Ca}, \mathrm{Mg}$ and Fe than CSF plants and significantly lower accumulations of Zn. Plants

285 from ASD2 plots exceeded both ASD1 and CSF plants in N, P and K accumulation as well, while both

286 ASD1 and ASD2 plants had higher accumulation of $\mathrm{Ca}, \mathrm{Mg}$ and Fe than CSF plants. Soil treatments did

287 not affect total plant accumulation of $\mathrm{Na}, \mathrm{B}, \mathrm{Cu}, \mathrm{Na}, \mathrm{Mo}$ or $\mathrm{Ni}$.

288 There were also significant differences in nutrient accumulation in stems, leaves, and fruits at the

289 Immokalee site. Both ASD1 and ASD2 plants had higher accumulations of $\mathrm{Na}, \mathrm{Zn}$, and Mn in stems than

290 CSF plants, but soil treatments had no effect on accumulation of other elements in plant stems.

291 Regardless of molasses rate, accumulation of $\mathrm{N}, \mathrm{K}, \mathrm{Ca}, \mathrm{Mg}$, and Fe in plant leaves was consistently

292 higher in plants grown in both ASD1 and ASD2 plots than in plants grown in CSF plots. Conversely,

293 leaves of CSF plants accumulated significantly greater amounts of Zn and Mo than either ASD1 or ASD2

294 plants. Fruit of ASD2 plants accumulated significantly higher amounts of N, P, K, Ca, Mg, Na, Fe, B, Zn,

295 and Mo compared to fruit from both ASD1 and CSF plants.

296 Fewer differences in nutrient accumulation as an effect of treatment emerged at Citra (Table 4). Total

297 plant nutrient accumulations were not influenced by soil disinfestation treatments, with the exception of

298 Mn accumulation, which was nearly three times greater in plants grown in ASD2 plot than those grown in

299 CSF plots. ASD2 plots had a significantly higher accumulation of $\mathrm{Zn}$ in stems than CSF plant, but the 
accumulation of other elements did not differ significantly between treatments. Although differences were

301 not significant for most elements, plants grown in ASD2 plots accumulated significantly greater amounts

302 of N, P, and Mn in their leaves than CSF plants, and ASD1 plants also accumulated significantly more N

303 than did CSF plants. There were no significant differences attributable to soil treatments in nutrient

304 accumulation in fruit.

\section{3.3. Surface air sampling and $\mathrm{N}_{2} \mathrm{O}$ analysis}

306 Average $\mathrm{N}_{2} \mathrm{O}$ emissions from the polyethylene mulched beds ranged from 0 to $0.378 \mu \mathrm{g} \mathrm{m}^{-2} \mathrm{~h}^{-1}$ in

307 Immokalee and from 8.8 to $39.8 \mu \mathrm{g} \mathrm{m}^{-2} \mathrm{~h}^{-1}$ in Citra during the initial three (Citra) and four (Immokalee)

308 days after treatment application (Fig. 4). No significant differences in $\mathrm{N}_{2} \mathrm{O}$ emissions were observed

309 among CSF, ASD1 and ASD2-treated soil during this period at either location. In contrast, emissions

310 were at least one order of magnitude higher at both sites at 21 days after treatment application. Average

$311 \mathrm{~N}_{2} \mathrm{O}$ emissions at 21 days after treatment application ranged from 1.56 to $4.83 \mu \mathrm{g} \mathrm{m}^{-2} \mathrm{~h}^{1}$ at Immokalee

312 and from 303.4 to $1480.1 \mu \mathrm{g} \mathrm{m}^{-2} \mathrm{~h}^{-1}$ at Citra. At 21 days after treatment application, emissions from both

313 ASD treatments were significantly higher than the CSF treatments at Citra, but not in Immokalee. No

314 significant differences were observed between ASD1 and ASD2-treated soil at either site at 21 days after

315 treatment application.

\section{3.4. Soil and soil solution nutrient content}

317 Treatment effects on levels of plant nutrients present in the soil show patterns similar to those observed in 318 accumulation of nutrients in plants. More differences among treatments emerged at Immokalee than at

319 Citra and ASD2 exhibited the highest value for many nutrients. Soil disinfestation treatments did not

320 influence the soil C:N ratio, with one exception. In Immokalee, the C:N ratio was higher in CSF plots

321 than in ASD plots at the end of the crop cycle, regardless of the molasses rate (Table 5). In Immokalee, at

322 transplanting, three weeks after treatment application, the content of $\mathrm{K}, \mathrm{Na}, \mathrm{Fe}, \mathrm{Cu}, \mathrm{Zn}$, Mo and $\mathrm{Ni}$

323 measured in the top $30 \mathrm{~cm}$ of soil was higher in ASD than CSF plots, but no differences were observed

324 for the other nutrients assessed. Regardless of molasses rate, ASD plots had higher N, P, Zn and Mo than

325 CSF plots at the end of the crop cycle. No differences were observed for the other nutrients analyzed. In 
326 Citra, only soil K, Na, and Mo were higher in ASD than CSF plots at three weeks after treatment

327 application, and soil Ca content was higher only in ASD2 compared to CSF plots. Soil treatments had no

328 effect on soil nutrient content at the end of the crop cycle, except for $\mathrm{Na}$, which was higher in ASD2 than

$329 \quad$ ASD1 and CSF plots.

330 During the three-week treatment period in Immokalee (Table 6), the nutrient concentration of the soil

331 solution extracted by suction lysimeters at $30 \mathrm{~cm}$ depth was significantly influenced by soil disinfestation

332 treatments for all nutrients except Mo and a significant interaction was observed between soil treatments

333 and assessment dates for all nutrients except Fe, B and Mo. At 7 and 14 days after treatment application,

334 the soil solution $\mathrm{NO}_{3}{ }^{-}$concentration was significantly lower in both ASD1 and ASD2 plots than in CSF

335 plots. The $\mathrm{NO}_{3}{ }^{-}$concentration increased in CSF plots from $134.0 \mathrm{mg} \mathrm{L}^{-1}$ to $160.1 \mathrm{mg} \mathrm{L}^{-1}$ at 7 and 14 days

336 after treatment application, respectively. At 21 days after treatment application, the $\mathrm{NO}_{3}{ }^{-}$concentration of

337 the soil solution in ASD plots remained stable while it decreased to $20.1 \mathrm{mg} \mathrm{L}^{-1}$ in CSF plots. As a result,

338 there were no significant differences due to soil treatment in $\mathrm{NO}_{3}{ }^{-}$concentration at 21 days after treatment

339 application. The concentrations in solution of $\mathrm{K}, \mathrm{Ca}, \mathrm{Mg}, \mathrm{Na}, \mathrm{Fe}, \mathrm{Mn}$ and $\mathrm{Ni}$ were consistently

340 significantly higher in both ASD1 and ASD2 plots than in CSF plots at 7, 14 and 21 days after treatment

341 application. There was more variation in the effect of treatments for other nutrients. The P concentration

342 was significantly higher in ASD1 plots than either CSF or ASD2 plots at 7 days after treatment

343 application, but by 14 days after treatment application, P concentration increased in both ASD1 and

344 ASD2 plots and was significantly higher in both treatments than in CSF plots at 14 and 21 days after

345 treatment application. The concentration of $\mathrm{K}$ in solution was consistently higher in ASD than CSF plots,

346 but a significant decrease in K concentration was observed in ASD1 at 21 compared to 7 and 14 days

347 after treatment application. The concentration of $\mathrm{Ca}$ and $\mathrm{Mg}$ remained stable in CSF plots and decreased

348 over time in ASD plots. While Ca concentrations in the soil solution were significantly higher in ASD

349 plots than CSF plots at 7,14 and 21 days after treatment application, the concentration in both ASD1 and

350 ASD2 decreased between 14 and 21 days after treatment application. Similarly, Mg concentrations were

351 consistently higher in ASD than CSF plots, but decreases over time, particularly in ASD1 plots. 
352 Variations in micronutrient concentrations in the soil solution were less consistent for both treatments and 353 assessment dates. Soil solution Na concentration was highest in ASD plots, but decreased between 7 and 35414 days after treatment application in ASD1 plots and decreased between 14 and 21 days after treatment 355 application in ASD2 plots. At 7 days after treatment application the soil solution concentration of Fe, $\mathrm{Zn}$, $356 \mathrm{Mn}, \mathrm{Mo}$, and Ni in ASD1 plots was higher compared to CSF plots. However, differences in soil solution 357 concentration of these elements were relatively small and inconsistent at the end of the three-week 358 treatment period.

359 In Citra, the quantity of soil solution collected was inadequate to accurately assess the potential for 360 nutrient concentration from any soil treatment.

\section{Discussion}

363 The soil amendment with CPL (composted poultry litter) and molasses combined with the application of

364 TIF (totally impermeable film) mulch and saturation of the soil with water caused a rapid shift of the soil

365 environment from aerobic to anaerobic conditions, as observed in previous studies (Butler et al., 2014a;

366 Strauss and Kluepfel, 2015). The persistence of anaerobic conditions increased with the molasses rate, but

367 was different between the two locations, likely due to differences in soil type or perhaps to the slight

368 differences in soil temperature and water content at the two locations (Fig. 1 and 2). In contrast with the

369 findings of other authors (Momma, 2008; Momma et al., 2006; Rosskopf et al., 2015), soil pH did not

370 decrease in ASD plots and was not influenced by soil disinfestation treatments at either location. Instead,

371 soil pH increased slightly, became nearly neutral (7.1) after the three-week treatment period, and then

372 returned to initial levels at the end of the crop cycle. Similar results were reported by Butler et al. (2014b)

373 who observed a higher soil $\mathrm{pH}$ in ASD treatment than in a fallow control in the presence of moderate

374 temperatures $\left(15-24{ }^{\circ} \mathrm{C}\right)$. The authors suggested that soil $\mathrm{pH}$ probably increased due to the release of

375 basic cations from added organic materials without the release of sufficient organic acids during

376 anaerobic degradation of the added C-source to generate a decrease in soil $\mathrm{pH}$ as reported for other ASD

377 studies (Momma et al., 2006; Rosskopf et al., 2015). Alternatively, as observed by Katyal (1977) in three 
different soil types, ASD may have caused only a temporary drop of the soil $\mathrm{pH}$, which stabilized near neutrality after 21 days. However, in this study, the ASD treatment probably induced a soil $\mathrm{pH}$ decrease that was counterbalanced by the application of CPL, which is characterized by a high pH (Tiquia and

381 Tam, 2002). This suggests that the type of soil amendment used can influence soil $\mathrm{pH}$ under ASD

382 treatment.

383 Soil temperatures recorded in Citra were optimal for the efficacy of ASD treatment, while the moderate

384 temperatures recorded earlier in the spring season in Immokalee could be considered sub-optimal.

385 Temperature can play a significant role in the effectiveness of ASD treatments (Butler et al., 2014b;

386 Ebihara and Uematsu, 2014), but temperatures at both locations in this study resulted in anaerobic

387 conditions, indicating that $\mathrm{C}$ application was adequate under both temperature regimes. Soil disinfestation

388 treatments had no influence on soil temperature.

389 As expected, soil disinfestation treatments and especially the soil amendment with CPL and molasses

390 significantly influenced the total soil macro- and micro-nutrient content (Table 5). However, no

391 differences were observed between molasses rates at three weeks after treatment application. This

392 suggests that increases in soil $\mathrm{K}, \mathrm{Na}$, and microelement ( $\mathrm{Fe}, \mathrm{Cu}, \mathrm{Zn}, \mathrm{Mo}$, and $\mathrm{Ni}$ ) content in ASD plots

393 were mainly a result of the application of CPL. In fact, except for C and K, the addition of nutrients with

394 the application of molasses was substantially lower than with the CPL (Table 1). Despite the addition of

395 CPL and two rates of molasses, total $\mathrm{C}$ and $\mathrm{N}$ and the $\mathrm{C}: \mathrm{N}$ ratio were not influenced by the soil

396 disinfestation treatments three weeks after treatment application (Table 2). The similar C:N ratios across

397 treatments may be explained by the application of a soil amendment with both $\mathrm{C}$ and $\mathrm{N}$, by the relatively

398 low C:N ratio of CPL (8:1), and by the rapid mineralization of the labile organic matter. Under aerobic

399 conditions, decomposition of the added organic matter led to enhanced production of $\mathrm{CO}_{2}$ and $\mathrm{NH}_{4}^{+}$

400 relative to the fumigation treatment (Butler et al., 2014a; Katyal, 1977).

401 Soil $\mathrm{NH}_{4}{ }^{+}$can volatilize to ammonia $\left(\mathrm{NH}_{3}\right)$ and accumulate under the TIF mulch and in soil pores, or in

402 the presence of aerobic conditions, $\mathrm{NH}_{4}{ }^{+}$would be nitrified to $\mathrm{NO}_{2}{ }^{-}$and then to $\mathrm{NO}_{3}{ }^{-}$by aerobic nitrifying

403 soil bacteria. However, when the soil environment shifts to anaerobic conditions, nitrification is limited. 
As a result, the reverse process, dissimilatory nitrate reduction to ammonium (DNRA) performed by

405 various anaerobic bacteria may become prevalent, along with the denitrification. The latter is operated

406 mainly by facultative aerobic bacteria that can grow in the absence of oxygen reducing $\mathrm{NO}_{3}{ }^{-}$and $\mathrm{NO}_{2}^{-}$to

$407 \mathrm{~N}_{2} \mathrm{O}$ and $\mathrm{N}_{2}$ (Rosskopf et al., 2015; Tiedje, 1988). Moreover, $\mathrm{NO}_{3}{ }^{-}$present in the soil may be subject to

408 loss by leaching during the three-week treatment period if significant rainfall events (76 $\mathrm{mm}$ of rain in 3

409 days or $102 \mathrm{~mm}$ in 7 days; Simonne and Hochmuth, 2011) occur.

410 In Immokalee, the higher concentration of $\mathrm{P}, \mathrm{K}, \mathrm{Ca}$, and $\mathrm{Mg}$ measured in the soil solution of ASD plots

411 compared to CSF plots indicates that ASD may substantially increase the availability of these nutrients in

412 the soil. Considering that in this study, the main source of P and K were the CPL and the molasses,

413 respectively, these results highlight the importance of taking into account in the crop fertilization plan, the

414 amount of nutrients added to the soil with the organic amendments, in order to avoid nutrient excess and

415 potential losses.

416 The $\mathrm{NO}_{3}{ }^{-}$concentration in the soil solution was lower in ASD than in CSF plots during the entire three-

417 week treatment period. In addition to the $\mathrm{NO}_{3}-\mathrm{N}$ applied with the starter fertilizer, the high $\mathrm{NO}_{3}{ }^{-}$

418 concentration observed in the soil solution of CSF plots could be derived from chloropicrin hydrolysis

419 (Castro and Blesler, 1981) and in part from the mineralization of killed microorganisms resulting from the

420 fumigation (Hansen et al., 1990). In ASD plots, considering the relatively high C:N ratio of the molasses

421 (28:1) added to the soil and the rapid microbial population growth, it is possible that high amounts of $\mathrm{N}$

422 were immobilized by soil microorganisms. Alternatively, the low $\mathrm{NO}_{3}{ }^{-}$concentration of the soil solution

423 observed in ASD plots over the three weeks after treatment application may have been due to the

424 prevalence of $\mathrm{NH}_{4}-\mathrm{N}$ over $\mathrm{NO}_{3}-\mathrm{N}$ as observed by Butler et al. (2014a) in soil amended with CPL under

425 moderate anaerobic conditions and by Katyal (1977) in flooded soil amended with organic matter. These

426 results suggest that the anaerobic conditions created with the ASD treatment substantially limited the

427 activity of the obligate aerobic bacteria responsible for the ammonium nitrification. The lower $\mathrm{NO}_{3}{ }^{-}$

428 concentration in the soil solution of ASD plots could also be due to denitrification during the anaerobic

429 phase (Rosskopf et al., 2015; Tiedje, 1988). 
Nitrous oxide is produced in soils through microbial nitrification and denitrification (Maag and Vinther,

431 1996). Denitrification is considered the major source of $\mathrm{N}_{2} \mathrm{O}$ production in ASD plots since anaerobic

432 conditions prevailed (Fig. 3). The key factor limiting denitrification in most mineral soils is the

433 availability of an organic C-source (Charles et al., 2017; Cochran et al., 1997; Flessa and Beese, 1995).

434 Incorporation of CPL and molasses into the ASD treatments added an estimated 9,828 and 14,589 $\mathrm{kg} \mathrm{ha}^{-1}$

435 of $\mathrm{C}$ to the ASD treated soil. This, combined with the initial addition of water, resulted in reductions in

436 redox potentials within the systems that were conducive for denitrification (Fig. 3). Increased $\mathrm{N}_{2} \mathrm{O}$

437 emissions from the ASD treatments at both locations 21 days after treatment application may have been

438 due to favorable soil redox potentials (Charles et al., 2017). Yu et al. (2001) reported that $\mathrm{N}_{2} \mathrm{O}$

439 accumulated significantly for all soils tested at redox potentials ranging between +120 and $+250 \mathrm{mV}$. In

440 their study, $\mathrm{N}_{2} \mathrm{O}$ emissions were low when the redox potential values were higher than $+250 \mathrm{mV}$ or lower

441 than $+120 \mathrm{mV}$. Since those studies were performed using paddy soils in China and agricultural soils

442 planted to maize (Zea mays L.) and wheat (Triticum aestivum L.) in Belgium, there is some uncertainty

443 regarding anaerobic boundaries in soils from different regions of the world. In the current study, the redox

444 potentials for the ASD treatments were between 0 and $+250 \mathrm{mV}$ from $16 \mathrm{~d}$ to $21 \mathrm{~d}$ at Citra; and 0 to +300

$445 \mathrm{mV}$ in Immokalee. Earlier in the ASD treatments, redox potentials were lower than $+120 \mathrm{mV}$, suggesting

446 that $\mathrm{N}_{2} \mathrm{O}$ emissions were lower if these systems behave as described by Yu et al. (2001). Interestingly,

447 redox potential for the CSF treatments were between +200 and $+250 \mathrm{mV}$ for Immokalee and between 0

448 and $+200 \mathrm{mV}$ for Citra throughout the 21 days after treatment application. The lack of significant $\mathrm{N}_{2} \mathrm{O}$

449 emissions was probably due to C limitations. Nevertheless, in Immokalee, where the level of $\mathrm{N}_{2} \mathrm{O}$

450 emissions in CSF plots was similar to that of ASD plots, it is possible that the chloropicrin used as the

451 fumigant standard stimulated the production of $\mathrm{N}_{2} \mathrm{O}$ as observed in previous studies (Spokas and Wang,

452 2003; Spokas et al., 2005, 2006).

453 Aside from the availability of inorganic $\mathrm{N}$ and available $\mathrm{C}$, other factors modulating microbial $\mathrm{N}_{2} \mathrm{O}$

454 production may include soil temperature, soil moisture, and pH (Knowles, 1982; Luo et al., 2013;

455 Schaufler et al., 2010; Wu et al., 2010). Soil temperature directly impacts microorganism activity, soil 
aeration, substrate availability, and redistribution. Previous studies reported that $\mathrm{N}_{2} \mathrm{O}$ emissions were

457 synchronized with surface soil temperature (Bremner et al., 1980; Cheng et al., 2014; Schaufler et al.,

458 2010). Lu and Xu (2014) also reported that temperature increases in peat soil under flooding increased

$459 \mathrm{~N}_{2} \mathrm{O}$ emission rates and cumulative emissions significantly. It is likely that a portion of the emissions

460 measured after polyethylene film punching on 21 days after treatment application was due to

461 accumulation of $\mathrm{N}_{2} \mathrm{O}$ under the TIF mulch during the three-week period prior to sampling. Although the

46221 days after treatment application $\mathrm{N}_{2} \mathrm{O}$ emission rates were higher from ASD-treated plots in Citra, rates

463 were similar to those resulting from urea application in Chinese vegetable production (Xiong et al., 2006).

464 Instead, the peak $\mathrm{N}_{2} \mathrm{O}$ emission rates measured in Citra, 21 days after treatment application, were lower

465 than those measured in Scotland, in a grassland system amended with poultry manure at rates that

466 provided levels of total $\mathrm{N}$ similar to those applied in ASD2 plots combining CPL and molasses in this

467 study (Jones et al., 2005).

468 An improved understanding of total $\mathrm{N}_{2} \mathrm{O}$ emissions resulting from ASD and conventional fumigation

469 systems could be gained by season-long assessments.

470 One other notable observation in this study is the difference in the magnitude of $\mathrm{N}_{2} \mathrm{O}$ emissions between

471 the two sites (Fig. 4). Average emissions at the Citra site were typically an order of magnitude higher than

472 those at Immokalee. Soil temperature and moisture may have influenced these emissions. Maag and

473 Vinther (1996) reported that both factors significantly influenced $\mathrm{N}_{2} \mathrm{O}$ emissions from sandy loam soils,

474 while only temperature influenced emissions from coarse sandy soils. The soil at the Citra site was a

475 loamy sand, whereas the Immokalee soil was a fine sand. Furthermore, soil temperature (Fig. 1) and

476 moisture (Fig. 3) for the ASD treatments tended to be higher at Citra than at Immokalee.

477 The soil treatments did not result in significantly different effects on tomato plant growth and plant

478 biomass partitioning between leaf, stem, and fruit, either on fresh or dry weight basis. These results do not

479 explain the higher fruit yield observed in the same study at Immokalee for plants grown on ASD soil (Di

480 Gioia et al., 2016). Nevertheless, the higher fruit yield may be explained in part by the improved

481 nutritional status of the ASD plants. The higher total plant macronutrient accumulation, especially in 
ASD2 plants, was likely due to a higher availability of nutrients during the crop cycle in soil amended

483 with CPL and molasses. These results corroborate the findings of Butler et al. (2014a) who observed

484 higher concentrations of N, P, K, Ca and Mg in plants grown in solarized soil amended with CPL or CPL 485 and molasses.

486 At the end of the crop cycle, the amounts of nutrients found in the top $30 \mathrm{~cm}$ of soil in both sites suggest 487 that the ASD treatment may have a residual fertility effect after the first crop cycle. In this case, residual 488 nutrients may be exploited in a double cropping system (Butler et al., 2014a) or need to be properly 489 managed (i.e. introducing suitable cover crops as catch crops) to minimize the risk of nutrient loss into the 490 environment. Alternatively, soil should be amended with lower rates of CPL or with organic sources 491 characterized by a lower nutrient content. Moreover, pre-plant fertilization should be avoided or reduced 492 and in-season fertigation needs to be adjusted, taking into consideration the amount of nutrients added to 493 the soil with the organic amendment.

\section{Conclusions}

496 In conclusion, the results of this study suggest that the ASD treatment using CPL and molasses has a 497 significant impact on soil fertility, increasing the soil nutrient content and improving crop nutrition and 498 nutrient accumulation. Nevertheless, nutrients added to the soil with the organic amendments, and 499 particularly P and K should be adequately accounted to avoid surplus of nutrients and potential losses, 500 especially during the three-week treatment period prior to crop establishment. The data presented here are 501 preliminary in this regard and additional testing is required. Given the residual fertility of the organic 502 amendment, additional losses of nutrients may occur at the end of the crop cycle or may increase the 503 potential for employing the system over multiple cropping cycles. Moreover, the amendment of the soil

504 with a C-source and the anaerobic conditions created during the ASD treatment may facilitate 505 denitrification, thereby increasing $\mathrm{N}_{2} \mathrm{O}$ emissions. Therefore, the application of the ASD technique on a 506 larger scale will depend on a better understanding and management of the nutrients added to the soil with 507 the incorporation of the organic amendments. Additional studies are required to further assess the 
508 potential environmental impact of the ASD technique and evaluate the possibility of avoiding the

509 application of pre-plant fertilizer or to use alternative organic materials characterized by lower nutrient

510 concentrations without reducing the efficacy of ASD in managing soil-borne diseases, plant parasitic

511 nematodes, and weeds.

\section{Acknowledgements}

514 The research presented here was funded by the USDA, ARS, Areawide Project on Anaerobic Soil

515 Disinfestation. The authors wish to thank Wesley Schonborn, Chris Lasser, Peter D’Auito, Melissa

516 Edgerly, Michael Hensley, Shardy Sauveur, Zack Black, Alisheikh Atta, Gilma Castillo, and Joel Mendez

517 for their contributions to the project.

518 Mention of trade names or commercial products in this publication is solely for the purpose of providing

519 specific information and does not imply recommendation or endorsement by the U.S. Department of

520 Agriculture. USDA is an equal opportunity provider and employer.

521

522

523 Benoit, M., Garnier, J., Billen, G., Tournebize, J., Gréhan, E., Mary, B., 2015. Nitrous oxide emissions

524 and nitrate leaching in an organic and a conventional cropping system (Seine basin, France). Agr.

$525 \quad$ Ecosyst. Environ. 213, 131-141.

Bremner, J.M., Robbins, S.G., Blackmer, A.M., 1980. Seasonal variability in emission of nitrous-oxide from soil. Geophys. Res. Lett. 7, 641-644.

Butler, D.M., Kokalis-Burelle, N., Albano, J.P., McCollum, T.G., Muramoto, J., Shennan, C., Rosskopf, 529 E.N., 2014a. Anaerobic soil disinfestation (ASD) combined with soil solarization as a methyl bromide $530 \quad$ alternative: Vegetable crop performance and soil nutrient dynamics. Plant Soil 378, 365-381.

531 Butler, D.M., Kokalis-Burelle, N., Muramoto, J., Shennan, C., McCollum, T.G., Rosskopf, E.N., $2012 \mathrm{a}$. 532 Impact of anaerobic soil disinfestation combined with soil solarization on plant-parasitic nematodes 
and introduced inoculum of soilborne plant pathogens in raised-bed vegetable production. Crop Prot.

$534 \quad 39,33-40$.

535 Butler, D.M., Ownley, B.H., Dee, M.E., Eichler Inwood, S.E., McCarty, D.G., Shrestha, U., Kokalis-

536 Burelle, N., Rosskopf, E.N., 2014b. Low carbon amendment rates during anaerobic soil disinfestation

537 (ASD) at moderate soil temperatures do not decrease viability of Sclerotinia sclerotiorum sclerotia or

538 fusarium root rot of common bean. Acta hortic. 1044, 203-208.

539 Butler, D.M., Rosskopf, E.N., Kokalis-Burelle, N., Albano, J.P., Muramoto, J., Shennan, C., 2012 b.

540 Exploring warm-season cover crops as carbon sources for anaerobic soil disinfestation (ASD). Plant

$541 \quad$ Soil $355,149-165$.

542 Castro, C.E., Belser, N.O., 1981. Photohydrolysis of methyl bromide and chloropicrin. J. Agric. Food

$543 \quad$ Chem. 29, 1005-1008.

544 Charles, A., Rochette, P., Whalen, J.K., Angers, D.A., Chantigny, M.H., Bertrand, N., 2017. Global

545 nitrous oxide emission factors from agricultural soils after addition of organic amendments: A meta-

546 analysis. Agr. Ecosyst. Environ. 236, 88-98.

547 Cheng, Y., Wang, J., Wang, S., Cai, Z., Wang, L., 2014. Effects of temperature change and tree species

548 composition on $\mathrm{N}_{2} \mathrm{O}$ and $\mathrm{NO}$ emissions in acidic forest soils of subtropical China. J. Environ. Sci.

$549 \quad$ (China) 26, 617-625.

550 Cochran, V.L., Sparrow, E.B., Schlentner, S.F., Knight, C.W., 1997. Long-term tillage and crop residue 551 management in the subarctic: fluxes of methane and nitrous oxide. Can. J. Soil Sci. 77, 565-570.

552 Di Gioia, F., Ozores-Hampton, M., Hong, J., Kokalis-Burelle, N., Albano, J., Zhao, X., Black, Z., Gao, 553 Z., Wilson, C., Thomas, J., Moore, K., Swisher, M., Guo, H., Rosskopf, E.N., 2016. The effects of 554 anaerobic soil disinfestation on weed and nematode control, fruit yield and quality of Florida fresh555 market tomato. HortScience 51, 703-711.

556 Ebihara, Y., Uematsu, S., 2014. Survival of strawberry-pathogenic fungi Fusarium oxysporum f. sp.

557 fragariae, Phytophthora cactorum and Verticillium dahliae under anaerobic conditions. J. Gen. Plant $558 \quad$ Pathol. 80, 50-58. 
Flessa, H., Beese, F., 1995. Effects of sugar-beet residues on soil redox potential and nitrous-oxide emission. Soil Sci. Soc. Am. J. 59, 1044-1051.

561 Florida Department of Agriculture and Consumer Services (FDACS), 2005. Water quality/quantity best 562 management practice manual for Florida vegetable and agronomic crops.

563 http://www.freshfromflorida.com/content/download/32110/789059/Bmp_VeggieAgroCrops2005.pdf $564 \quad$ (accessed 01.12.16).

565 Hansen, E.M., Myrold, D.D., Hamm, P.B., 1990. Effects of soil fumigation and cover crops on potential 566 pathogens, microbial activity, nitrogen availability, and seedling quality in conifer nurseries.

567 Phytopathology 80, 698-704.

568 Hubaux, A., Vos, G., 1970. Decision and detection limits for linear calibration curves. Anal. Chem. 42, $569 \quad 849-855$.

570 Jones, S. K., Rees, R.M., Skiba, U.M., Ball, B.C., 2005. Greenhouse gas emissions from a managed 571 grassland. Glob. Planet. Change 47, 201-211.

572 Katyal, J.C., 1977. Influence of organic matter on the chemical and electrochemical properties of some 573 flooded soils. Soil Biol. Biochem. 9, 259-266.

574 Knowles, R., 1982. Denitrification. Microbiol. Rev. 46, 43-70.

575 Lamers, J.G., Runia, W.T., Molendijk, L.P.G., Bleeker, P.O., 2010. Perspectives of anaerobic soil 576 disinfestation. Acta Hortic. 883, 277-284.

577 Littell, R.C., Henry, P.R., Ammerman, C.B., 1998. Statistical analysis of repeated measures data using 578 SAS procedures. J. Anim. Sci. 76, 1216-1231.

579 Lu, Y., Xu, H.W., 2014. Effects of soil temperature, flooding, and organic matter addition on $\mathrm{N}_{2} \mathrm{O}$ 580 emissions from a soil of Hongze Lake Wetland, China. Sci. World J. pp. 7.

581 Luo, G.J., Kiese, R., Wolf, B., Butterbach-Bahl, K. 2013. Effects of soil temperature and moisture on 582 methane uptake and nitrous oxide emissions across three different ecosystem types. Biogeosciences $583 \quad 10,3205-3219$. 
Maag, M., Vinther, F.P., 1996. Nitrous oxide emission by nitrification and denitrification in different soil types and at different soil moisture contents and temperatures. Appl. Soil Ecol. 4, 5-14.

Momma, N., 2008. Biological soil disinfestation (BSD) of soilborne pathogens and its possible mechanisms. Japan Agric. Res. Q. 42, 7-12.

Momma, N., Yamamoto, K., Simandi, P., Shishido, M., 2006. Role of organic acids in the mechanisms of biological soil disinfestation (BSD). J. Gen. Plant Pathol. 72, 247-252.

Mowlick, S., Hirota, K., Takehara, T., Kaku, N., Ueki, K., Ueki, A., 2012. Development of anaerobic bacterial community consisted of diverse clostridial species during biological soil disinfestation amended with plant biomass. Soil Sci. Plant Nutr. 58, 273-287.

Mowlick, S., Inoue, T., Takehara, T., Kaku, N., Ueki, K., Ueki, A., 2013a. Changes and recovery of soil

594 bacterial communities influenced by biological soil disinfestation as compared with chloropicrin-

$595 \quad$ treatment. AMB Express 3, 46.

Mowlick, S., Takehara, T., Kaku, N., Ueki, K., Ueki, A., 2013b. Proliferation of diversified clostridial species during biological soil disinfestation incorporated with plant biomass under various conditions. Appl. Microbiol. Biotechnol. 97, 8365-8379.

Oka, Y., 2010. Mechanisms of nematode suppression by organic soil amendments - a review. Appl. Soil Ecol. 44, 101-115.

601 Ozores-Hampton, M., Di Gioia, F., Sato, S., Simonne, E., Morgan, K., 2015. Effects of nitrogen rates on 602 nitrogen, phosphorous, and potassium partitioning, accumulation, and use efficiency in seepage-

603 irrigated fresh market tomatoes. HortScience 50, 1636-1643.

604 Ravishankara, A.R., Daniel, J.S., Portmann, R.W., 2009. Nitrous oxide $\left(\mathrm{N}_{2} \mathrm{O}\right)$ : the dominant ozone605 depleting substance emitted in the $21^{\text {st }}$ century. Science $326,123-125$.

606 Rosskopf, E.N., Serrano-Pérez, P., Hong, J., Shrestha, U., Rodríguez-Molina, M.C., Martin, K., Kokalis607 Burelle, N., Shennan, C., Muramoto, J., Butler, D., 2015. Anaerobic soil disinfestation and soil borne 

277-305.

611 Schaufler, G., Kitzler, B., Schindlbacher, A., Skiba, U., Sutton, M.A., Zechmeister-Boltenstern, S., 2010.

612 Greenhouse gas emissions from European soils under different land use: effects of soil moisture and

613 temperature. Eur. J. Soil Sci. 61, 683-696.

614 Shennan, C., Muramoto, J., Lamers, J., Mazzola, M., Rosskopf, E.N., Kokalis-Burelle, N., Momma, N.,

615 Butler, D.M., Kobara, Y., 2014. Anaerobic soil disinfestation for soil borne disease control in

616 strawberry and vegetable systems: current knowledge and future directions. Acta Hortic. 1044, 165-

$617 \quad 175$.

618 Shinmura, A., Sakamoto, N., Abe, H., 1999. Control of Fusarium root rot of Welsh onion by soil

619 reduction (abstract in Japanese). Jpn. J. Phytopathol. 65, 352-353.

620 Simonne, E.H., Hochmuth, G.J., 2011. Soil and fertilizer management for vegetable production in

621 Florida, in Olson, S.M., Bielinsky, S., (Eds.), Vegetable Production Handbook for Florida, 2011-2012.

622 University of Florida Institute of Food and Agricultural Sciences, Gainesville, pp. 3-16.

623 Spokas, K., Wang, D., 2003. Stimulation of nitrous oxide production resulted from soil fumigation with

624 chloropicrin. Atmos. Environ. 37, 3501-3507.

625 Spokas, K., Wang, D., Venterea, R., 2005. Greenhouse gas production and emission from a forest nursery

626 soil following fumigation with chloropicrin and methyl isothiocyanate. Soil Biol. Biochem. 37, 475-

627485.

628 Spokas, K., Wang, D., Venterea, R., Sadowsky, M., 2006. Mechanisms of $\mathrm{N}_{2} \mathrm{O}$ production following

629 chloropicrin fumigation. Appl. Soil Ecol. 31, 101-109.

630 Tiedje, J.M., 1988. Ecology of denitrification and dissimilatory nitrate reduction to ammonium, in

631 Zehnder, A.J.B., (Eds.), Environmental Microbiology of Anaerobes. John Wiley and Sons, New York, 632 pp. 179-244.

633 Tiquia, S.M., Tam, N.F.Y., 2002. Characterization and composting of poultry litter in forced-aeration 634 piles. Process Biochem. 37, 869-880. 
635 van Agtmaal, M., van Os, G.J., Hol, W.G., Hundscheid, M.P.J., Runia. W.T., Hordijk, C.A., de Boer, W.,

636 2015. Legacy effects of anaerobic soil disinfestation on soil bacterial community composition and

637 production of pathogen-suppressing volatiles. Front. Microb. 6, 1-12.

638 Wu, X., Yao, Z., Bruggemann, N., Shen, ZY., Wolf. B., Dannenmann, M., Zheng, X., Butterbach-Bahl,

639 K., 2010. Effects of soil moisture and temperature on $\mathrm{CO}_{2}$ and $\mathrm{CH}_{4}$ soil atmosphere exchange of

640 various land use/cover types in a semi-arid grassland in Inner Mongolia, China. Soil Biol. Biochem.

$641 \quad 42,773-787$.

642 Xiong, Z., Xie, Y., Xing, G., Zhu, Z., Butenhoff. C., 2006. Measurements of nitrous oxide emissions from 643 vegetable production in China. Atmos. Environ. 40, 2225-2234.

644 Yu, K.W., Wang, Z.P., Vermoesen, A., Patrick, W.H., Van Cleemput, O., 2001. Nitrous oxide and

645 methane emissions from different soil suspensions: effect of soil redox status. Biol. Fert. Soils 34, 25-

64630. 
647 Table 1. Mean ( \pm standard deviation; $n=3$ ) nutrient content of molasses and composted poultry litter and 648 total amounts of nutrients applied with the anaerobic soil disinfestation (ASD) treatments in Immokalee 649 and Citra, FL, in the spring of 2015.

\begin{tabular}{|c|c|c|c|c|c|c|c|c|c|c|c|c|}
\hline \multirow{3}{*}{ Nutrient } & \multicolumn{3}{|c|}{ Molasses } & \multicolumn{3}{|c|}{$\begin{array}{l}\text { Composted } \\
\text { poultry litter } \\
(\mathrm{CPL})\end{array}$} & \multicolumn{3}{|c|}{$\mathrm{ASD}^{\mathrm{z}}$} & \multicolumn{3}{|c|}{$\mathrm{ASD}^{\mathrm{z}}$} \\
\hline & Mean & & SD & Mean & & $\mathrm{SD}$ & Molasses & CPL & Total & Molasses & CPL & Total \\
\hline & \multicolumn{3}{|c|}{$\mathrm{g} \mathrm{L}^{-1}$} & \multicolumn{3}{|c|}{$\mathrm{g} \mathrm{kg}^{-1}$} & \multicolumn{3}{|c|}{$\mathrm{kg} \mathrm{ha}^{-1}$} & \multicolumn{3}{|c|}{$\mathrm{kg} \mathrm{ha}^{-1}$} \\
\hline $\mathrm{N}$ & 12.3 & \pm & 0.75 & 26.1 & \pm & 1.46 & 171 & 574 & 745 & 341 & 574 & 915 \\
\hline $\mathrm{C}$ & 342.5 & \pm & 12.59 & 230.3 & \pm & 25.72 & 4,748 & 5,067 & 9,815 & 9,489 & 5,067 & $\begin{array}{r}14,55 \\
6\end{array}$ \\
\hline $\mathrm{P}$ & 0.8 & \pm & 0.01 & 14 & \pm & 0.82 & 11 & 308 & 319 & 22 & 308 & 330 \\
\hline $\mathrm{K}$ & 51.6 & \pm & 0.52 & 25 & \pm & 0.57 & 715 & 550 & 1,265 & 1,430 & 550 & 1,980 \\
\hline $\mathrm{Ca}$ & 9.8 & \pm & 0.09 & 22.6 & \pm & 0.46 & 136 & 497 & 633 & 272 & 497 & 769 \\
\hline $\mathrm{Mg}$ & 3.8 & \pm & 0.03 & 5.2 & \pm & 0.02 & 53 & 114 & 167 & 105 & 114 & 220 \\
\hline $\mathrm{Na}$ & 0.8 & \pm & 0.01 & 8.6 & \pm & 0.28 & 11 & 189 & 200 & 22 & 189 & 211 \\
\hline $\mathrm{Fe}$ & 125.1 & \pm & 2.12 & 396.6 & \pm & 88.84 & 1.73 & 8.73 & 10.46 & 3.47 & 8.73 & 12.19 \\
\hline B & 6.8 & \pm & 0.88 & 48.8 & \pm & 1.22 & 0.09 & 1.07 & 1.17 & 0.19 & 1.07 & 1.26 \\
\hline $\mathrm{Cu}$ & 2.6 & \pm & 0.14 & 421.2 & \pm & 12.83 & 0.04 & 9.27 & 9.30 & 0.07 & 9.27 & 9.34 \\
\hline $\mathrm{Zn}$ & 11.2 & \pm & 0.2 & 478.1 & \pm & 10.47 & 0.16 & 10.52 & 10.67 & 0.31 & 10.52 & 10.83 \\
\hline $\mathrm{Mn}$ & 8.3 & \pm & 0.37 & 418.8 & \pm & 1.89 & 0.12 & 9.21 & 9.33 & 0.23 & 9.21 & 9.44 \\
\hline $\mathrm{Ni}$ & 1.3 & \pm & 0.34 & 9.8 & \pm & 3.84 & 0.02 & 0.22 & 0.23 & 0.04 & 0.22 & 0.25 \\
\hline Mo & 1.1 & \pm & 0.02 & 4.3 & \pm & 0.57 & 0.02 & 0.09 & 0.11 & 0.03 & 0.09 & 0.13 \\
\hline
\end{tabular}

$651{ }^{\mathrm{z}}$ ASD1 (anaerobic soil disinfestation with $13.9 \mathrm{~m}^{3} \mathrm{ha}^{-1}$ of molasses and $22 \mathrm{Mg} \mathrm{ha}^{-1}$ of composted poultry

652 litter), ASD2 (anaerobic soil disinfestation with $27.7 \mathrm{~m}^{3} \mathrm{ha}^{-1}$ of molasses and $22 \mathrm{Mg} \mathrm{ha}^{-1}$ of composted 653 poultry litter). 
654 Table 2. Soil treatment effects on leaves, stem, fruit, and total plant fresh and dry weight of fresh-market

655 tomatoes grown in Immokalee (University of Florida/Institute of Food and Agricultural

656 Science/Southwest Florida Research and Education Center) and in Citra (University of Florida/Plant

657 Science Research and Education Unit) in the spring of $2015 .{ }^{\mathrm{z}}$

\begin{tabular}{|c|c|c|c|c|c|c|c|c|}
\hline \multirow{2}{*}{ Soil treatment ${ }^{\mathrm{y}}$} & \multicolumn{4}{|c|}{ Fresh weight $\left(\right.$ g plant $\left.^{-1}\right)$} & \multicolumn{4}{|c|}{ Dry weight $\left(\right.$ g plant $\left.^{-1}\right)$} \\
\hline & Leaves & Stem & Fruit & Total & Leaves & Stem & Fruit & Total \\
\hline & \multicolumn{8}{|c|}{ Immokalee, FL } \\
\hline CSD & 668.6 & 419.6 & $1,860.9$ & $2,949.1$ & 70.6 & 43.3 & 48.6 & 162.5 \\
\hline ASD1 & 763.8 & 449.4 & $1,879.2$ & $3,092.4$ & 79.5 & 43.3 & 50.4 & 173.2 \\
\hline ASD2 & 774.1 & 462.8 & $1,695.4$ & $2,932.3$ & 81.7 & 44.2 & 45.4 & 171.3 \\
\hline \multirow[t]{2}{*}{ P value } & 0.71 & 0.91 & 0.79 & 0.92 & 0.67 & 0.99 & 0.80 & 0.91 \\
\hline & \multicolumn{8}{|c|}{ Citra, FL } \\
\hline $\mathrm{CSD}$ & 153.6 & 135.0 & 657.9 & 946.5 & 26.9 & 23.1 & 42.5 & 92.5 \\
\hline ASD1 & 296.1 & 210.4 & 837.8 & $1,344.3$ & 47.0 & 35.1 & 52.3 & 134.4 \\
\hline ASD2 & 374.4 & 274.9 & 809.4 & $1,458.6$ & 56.9 & 44.9 & 55.6 & 157.4 \\
\hline Pvalue & 0.10 & 0.14 & 0.78 & 0.43 & 0.15 & 0.17 & 0.80 & 0.34 \\
\hline
\end{tabular}

658

$659{ }^{\mathrm{z}}$ Reported values are averages of four replications. Means followed by different letters within each

660 column and location are significantly different at $\alpha=0.05$ by Duncan's multiple range test. ${ }^{\mathrm{y}}$ CSF

661 (chemical soil fumigation), ASD1 (anaerobic soil disinfestation with $13.9 \mathrm{~m}^{3} \mathrm{ha}^{-1}$ of molasses), ASD2

662 (anaerobic soil disinfestation with $27.7 \mathrm{~m}^{3} \mathrm{ha}^{-1}$ of molasses). 
664 during the spring of $2015 .^{\mathrm{z}}$

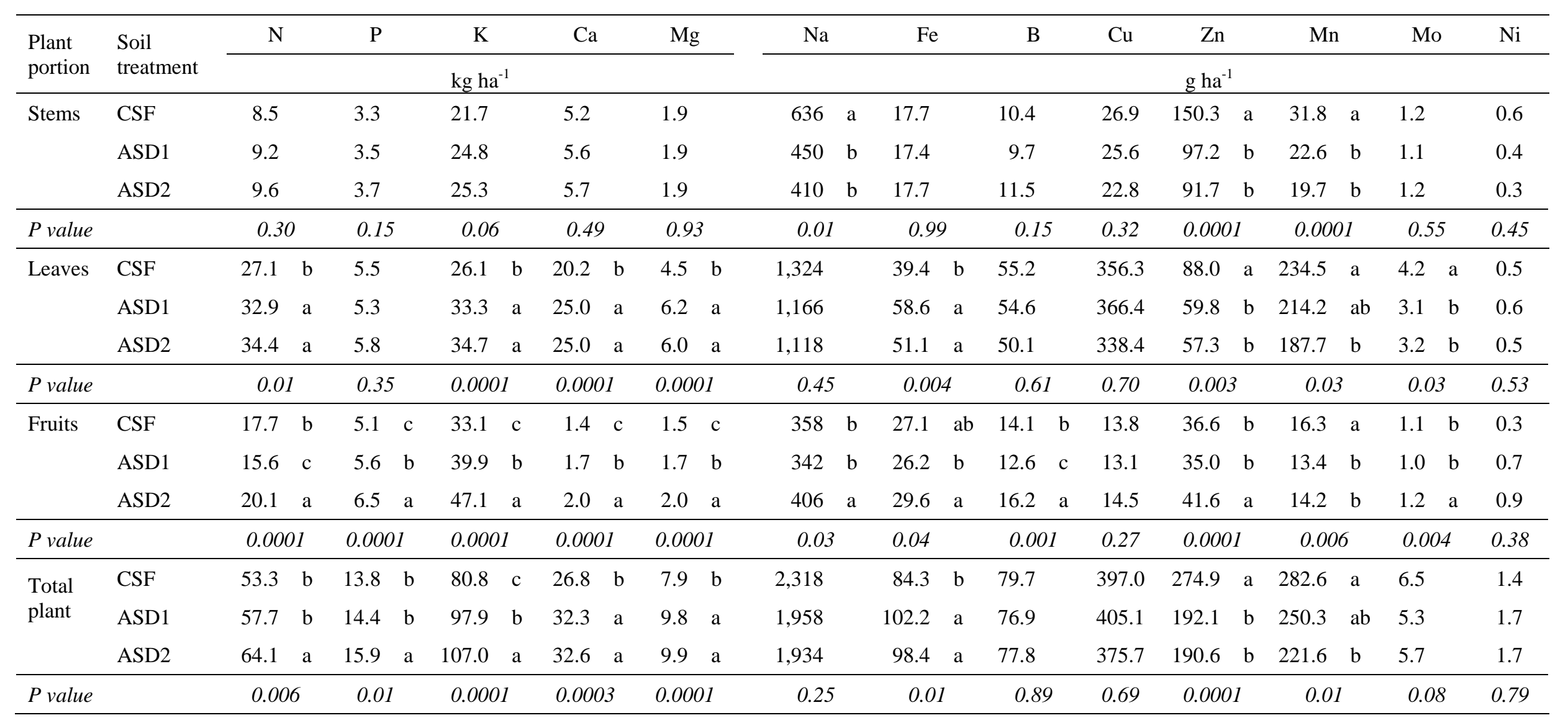

$666{ }^{\mathrm{z}}$ Reported values are averages of four replications. Means followed by different letters within each column and plant portion are significantly

667 different at $\alpha=0.05$ by Duncan's multiple range test. ${ }^{y}$ CSF (chemical soil fumigation), ASD1 (anaerobic soil disinfestation with $13.9 \mathrm{~m}^{3}$ ha ${ }^{-1}$ of

668 molasses), ASD2 (anaerobic soil disinfestation with $27.7 \mathrm{~m}^{3} \mathrm{ha}^{-1}$ of molasses). 
670 the spring of $2015 .^{\mathrm{z}}$

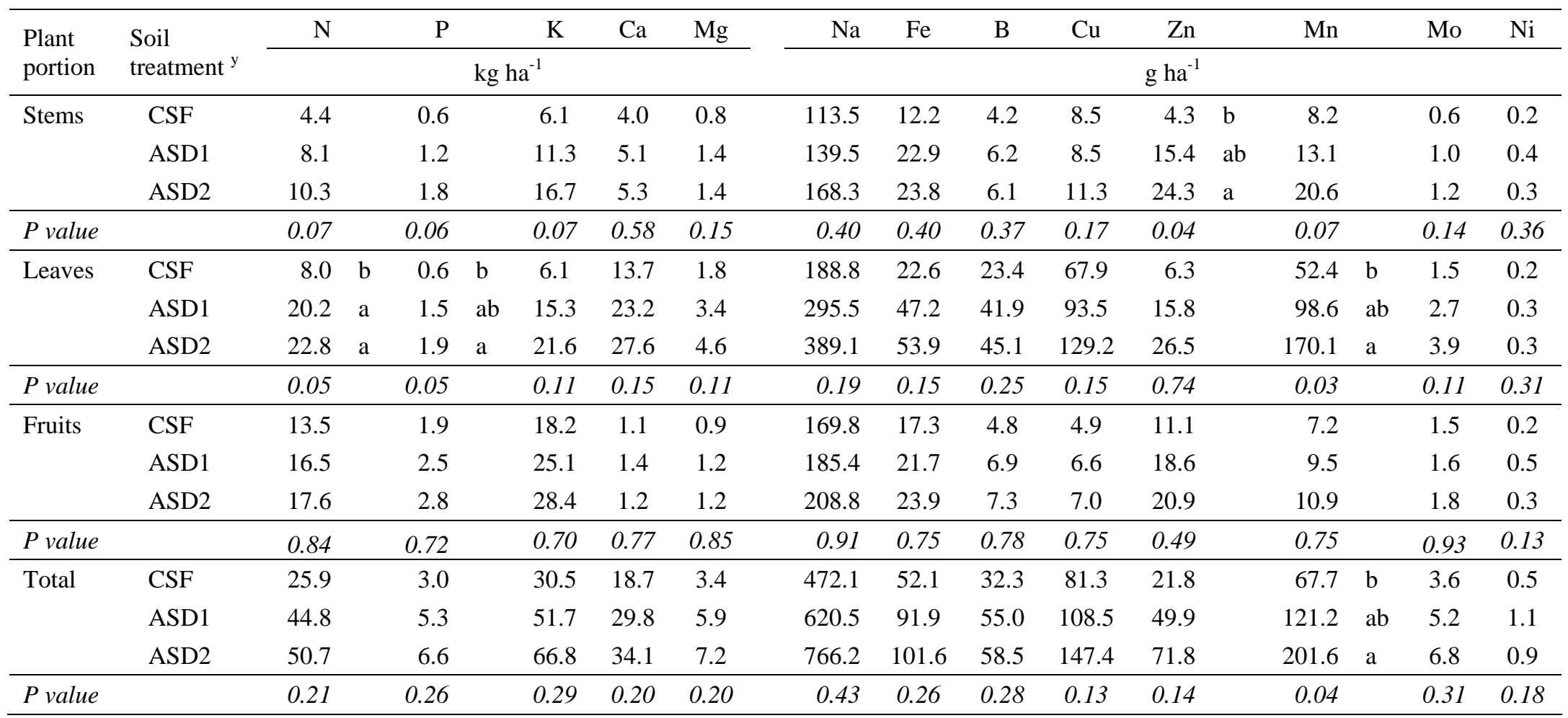

$672{ }^{\mathrm{z}}$ Reported values are averages of four replications. Means followed by different letters within each column and plant portion are significantly

673 different at $\alpha=0.05$ by Duncan's multiple range test. ${ }^{y}$ CSF (chemical soil fumigation), ASD1 (anaerobic soil disinfestation with $13.9 \mathrm{~m}^{3}$ ha ${ }^{-1}$ of

674 molasses), ASD2 (anaerobic soil disinfestation with $27.7 \mathrm{~m}^{3} \mathrm{ha}^{-1}$ of molasses). 
678 at the end of the crop cycle, in Immokalee and in Citra in the spring of 2015 . $^{\mathrm{z}}$

\begin{tabular}{|c|c|c|c|c|c|c|c|c|c|c|c|c|c|c|c|}
\hline \multirow{2}{*}{$\begin{array}{l}\text { Soil } \\
\text { Treatment }\end{array}$} & \multirow{2}{*}{$\begin{array}{l}\mathrm{C}: \mathrm{N} \\
\text { ratio }\end{array}$} & $\mathrm{N}$ & $\mathrm{C}$ & $\mathrm{P}$ & $\mathrm{K}$ & $\mathrm{Ca}$ & $\mathrm{Mg}$ & $\mathrm{Na}$ & $\mathrm{Fe}$ & $\mathrm{B}$ & $\mathrm{Cu}$ & $\mathrm{Zn}$ & $\mathrm{Mn}$ & Mo & $\mathrm{Ni}$ \\
\hline & & \multicolumn{14}{|c|}{$\mathrm{kg} \mathrm{ha}^{-1}$} \\
\hline \multicolumn{16}{|c|}{ Immokalee, FL } \\
\hline \multicolumn{16}{|c|}{ Pre-treatment } \\
\hline Untreated & 14.2 & 1,454 & 20,529 & 43.8 & 112 & 141 & 64.1 & 21.76 & 3.99 & 0.01 & 0.35 & 1.00 & 0.91 & 0.01 & 0.11 \\
\hline \multicolumn{16}{|l|}{ Planting } \\
\hline $\mathrm{CSF}$ & 14.1 & 1,908 & 26,201 & 55.3 & $68 \mathrm{~b}$ & 158 & 47.1 & $26.2 \mathrm{~b}$ & $3.65 \mathrm{~b}$ & 0.45 & $0.38 \mathrm{~b}$ & $0.75 \mathrm{~b}$ & 1.89 & $0.03 \mathrm{~b}$ & $0.09 \mathrm{~b}$ \\
\hline ASD1 & 12.8 & 1,864 & 23,550 & 68.0 & $891 \mathrm{a}$ & 137 & 56.0 & $131.6 \mathrm{a}$ & $8.37 \mathrm{a}$ & 2.03 & $2.59 \mathrm{a}$ & $1.49 \mathrm{a}$ & 2.30 & $0.11 \mathrm{a}$ & $0.20 \mathrm{a}$ \\
\hline ASD2 & 14.3 & 1,992 & 27,075 & 73.4 & $1,172 \mathrm{a}$ & 197 & 77.5 & $119.4 \mathrm{a}$ & $8.60 \mathrm{a}$ & 1.51 & $2.28 \mathrm{a}$ & $1.52 \mathrm{a}$ & 2.98 & $0.11 \mathrm{a}$ & $0.31 \mathrm{a}$ \\
\hline$P$-value & 0.54 & 0.98 & 0.86 & 0.30 & 0.001 & 0.43 & 0.23 & 0.004 & 0.02 & 0.11 & 0.004 & 0.02 & 0.48 & 0.002 & 0.01 \\
\hline \multicolumn{16}{|c|}{ End of the crop } \\
\hline CSF & $14.2 \mathrm{a}$ & $1,564 \mathrm{~b}$ & 21,936 & $24.5 \mathrm{~b}$ & 41 & 79.8 & 14.4 & 23.46 & 4.92 & 0.42 & 0.59 & $0.57 \mathrm{~b}$ & 1.08 & $0.02 \mathrm{~b}$ & 0.10 \\
\hline ASD1 & $13.1 \mathrm{~b}$ & $2,139 \mathrm{a}$ & 27,892 & $46.0 \mathrm{a}$ & 54 & 77.9 & 23.5 & 53.74 & 5.56 & 0.58 & 0.91 & $0.74 \mathrm{a}$ & 0.81 & $0.03 \mathrm{a}$ & 0.16 \\
\hline ASD2 & $13.3 \mathrm{~b}$ & $2,159 \mathrm{a}$ & 28,549 & $43.7 \mathrm{a}$ & 107 & 93.8 & 28.0 & 66.46 & 4.81 & 0.74 & 0.82 & $0.61 \mathrm{ab}$ & 0.70 & $0.04 \mathrm{a}$ & 0.13 \\
\hline$P$-value & 0.03 & 0.05 & 0.09 & 0.01 & 0.33 & 0.61 & 0.17 & 0.10 & 0.23 & 0.13 & 0.13 & 0.05 & 0.07 & 0.02 & 0.30 \\
\hline \multicolumn{16}{|c|}{ Citra, FL } \\
\hline \multicolumn{16}{|c|}{ Pre-treatment } \\
\hline Untreated & 18.6 & 2,470 & 45,263 & 21.0 & 64 & 33 & 5.7 & 7.78 & 20.42 & 0.16 & 0.22 & 0.10 & 0.35 & 0.02 & 0.10 \\
\hline \multicolumn{16}{|l|}{ Planting } \\
\hline $\mathrm{CSF}$ & 17.38 & 2,929 & 50,113 & 24.5 & $218 b$ & $41 \mathrm{~b}$ & 6.6 & $14.6 \mathrm{~b}$ & 22.25 & 0.39 & 0.20 & 0.04 & 0.31 & $0.02 \mathrm{~b}$ & 0.02 \\
\hline ASD1 & 16.96 & 3,315 & 52,375 & 35.9 & $1,869 \mathrm{a}$ & $176 a b$ & 60.1 & $223.5 \mathrm{a}$ & 25.31 & 0.65 & 2.84 & 0.54 & 2.59 & $0.10 \mathrm{a}$ & 0.21 \\
\hline ASD2 & 15.27 & 4,085 & 56,050 & 40.7 & $2,178 \mathrm{a}$ & $276 \mathrm{a}$ & 104.6 & $203.5 \mathrm{a}$ & 29.46 & 1.17 & 2.47 & 0.67 & 4.76 & $0.08 \mathrm{a}$ & 0.26 \\
\hline$P$-value & 0.27 & 0.28 & 0.60 & 0.50 & 0.02 & 0.03 & 0.06 & 0.003 & 0.60 & 0.10 & 0.10 & 0.30 & 0.08 & 0.03 & 0.08 \\
\hline \multicolumn{16}{|c|}{ End of the crop } \\
\hline CSF & 23.97 & 1,948 & 46,368 & 17.7 & 103 & 102 & 13.1 & $13.4 \mathrm{~b}$ & 23.57 & 0.22 & 0.10 & 0.09 & 0.42 & 0.01 & 0.05 \\
\hline ASD1 & 22.56 & 1,924 & 42,691 & 22.1 & 174 & 118 & 24.1 & $16.0 \mathrm{~b}$ & 25.05 & 0.21 & 0.22 & 0.11 & 0.54 & 0.02 & 0.07 \\
\hline ASD2 & 18.95 & 2,632 & 49,705 & 11.2 & 316 & 235 & 48.0 & $42.9 \mathrm{a}$ & 13.40 & 0.25 & 0.15 & 0.08 & 0.77 & 0.00 & 0.04 \\
\hline$P$-value & 0.12 & 0.07 & 0.38 & 0.09 & 0.30 & 0.23 & 0.08 & 0.01 & 0.11 & 0.98 & 0.07 & 0.51 & 0.22 & 0.32 & 0.08 \\
\hline
\end{tabular}


$680{ }^{\mathrm{z}}$ Reported values are averages of four replications. Means followed by different letters within each column and location are significantly different 681 at $\alpha=0.05$ by Duncan's multiple range test. ${ }^{\mathrm{y}} \mathrm{CSF}$ (chemical soil fumigation), ASD1 (anaerobic soil disinfestation with $13.9 \mathrm{~m}^{3}$ ha ${ }^{-1}$ of molasses), 682 ASD2 (anaerobic soil disinfestation with $27.7 \mathrm{~m}^{3} \mathrm{ha}^{-1}$ of molasses). 
683 Table 6. Soil treatment effects on the nutrient concentration of the soil solution extracted with suction lysimeters at $30 \mathrm{~cm}$ depth in Immokalee in

684 the spring of $2015 .^{\mathrm{z}}$

\begin{tabular}{|c|c|c|c|c|c|c|c|c|c|c|c|c|c|c|c|c|c|c|c|c|c|c|c|c|c|c|c|}
\hline \multirow{2}{*}{ DATA $^{y}$} & \multirow{2}{*}{$\begin{array}{c}\text { Soil } \\
\text { treatment }\end{array}$} & $\mathrm{NO}_{3}^{-}$ & & \multicolumn{2}{|c|}{$\mathrm{P}$} & \multicolumn{2}{|c|}{$\mathrm{K}$} & \multicolumn{2}{|c|}{$\mathrm{Ca}$} & \multicolumn{2}{|c|}{$\mathrm{Mg}$} & \multirow{2}{*}{\multicolumn{2}{|c|}{$\mathrm{Na}$}} & \multirow{2}{*}{\multicolumn{2}{|c|}{$\frac{\mathrm{Fe}}{\mathrm{mg} \mathrm{L}^{-1}}$}} & \multirow{2}{*}{\multicolumn{2}{|c|}{ B }} & \multicolumn{2}{|c|}{$\mathrm{Cu}$} & \multicolumn{2}{|l|}{$\mathrm{Zn}$} & \multirow{2}{*}{\multicolumn{2}{|c|}{$\mathrm{Mn}$}} & \multicolumn{2}{|c|}{ Mo } & \multirow{2}{*}{\multicolumn{2}{|c|}{$\mathrm{Ni}$}} \\
\hline & & & & & & & & & & & & & & & & & & & & & & & & & & & \\
\hline \multirow{3}{*}{7} & CSF & 134.0 & $\mathrm{a}$ & 20.4 & $\mathrm{~b}$ & 30.1 & $\mathrm{c}$ & 189.0 & $\mathrm{de}$ & 43.0 & ed & 25.1 & $\mathrm{c}$ & 0.26 & $\mathrm{~b}$ & 0.30 & $\mathrm{bc}$ & 0.51 & $\mathrm{a}$ & 2.93 & $\mathrm{cb}$ & 1.43 & $\mathrm{~d}$ & 0.00 & $\mathrm{~b}$ & 0.04 & $\mathrm{de}$ \\
\hline & ASD1 & 5.6 & $b$ & 64.6 & $\mathrm{a}$ & 587.2 & a & 397.8 & $a b$ & 100.2 & a & 91.1 & $\mathrm{a}$ & 15.06 & a & 0.49 & $a b c$ & 0.64 & $\mathrm{a}$ & 11.84 & $\mathrm{a}$ & 10.44 & $\mathrm{a}$ & 0.03 & $\mathrm{a}$ & 0.13 & a \\
\hline & ASD2 & 7.7 & b & 33.7 & $\mathrm{~b}$ & 461.0 & $a b$ & 431.4 & $\mathrm{a}$ & 88.2 & $a b$ & 65.9 & $\mathrm{~b}$ & 3.40 & $a b$ & 0.68 & $a b c$ & 0.24 & $b$ & 2.64 & $\mathrm{cb}$ & 7.75 & $a b$ & 0.00 & $\mathrm{~b}$ & 0.10 & $a b$ \\
\hline \multirow{3}{*}{14} & CSF & 160.1 & $\mathrm{a}$ & 28.4 & $\mathrm{~b}$ & 41.2 & $\mathrm{c}$ & 225.4 & $\mathrm{~cd}$ & 51.1 & $\mathrm{~d}$ & 28.1 & $\mathrm{c}$ & 0.48 & $\mathrm{~b}$ & 1.16 & $\mathrm{a}$ & 0.59 & $\mathrm{a}$ & 3.38 & $\mathrm{cb}$ & 1.88 & $\mathrm{~cd}$ & 0.00 & $\mathrm{~b}$ & 0.05 & $\mathrm{~cd}$ \\
\hline & ASD1 & 4.1 & $\mathrm{~b}$ & 90.9 & $\mathrm{a}$ & 401.9 & $a b$ & 316.8 & $\mathrm{bc}$ & 67.2 & bcd & 57.2 & $\mathrm{~b}$ & 11.81 & $a b$ & 0.19 & $\mathrm{c}$ & 0.31 & b & 5.55 & $\mathrm{~b}$ & 8.39 & $a b$ & 0.00 & $\mathrm{~b}$ & 0.09 & $a b c$ \\
\hline & ASD2 & 8.3 & $\mathrm{~b}$ & 72.0 & $\mathrm{a}$ & 454.2 & $a b$ & 383.0 & $a b$ & 82.4 & $a b c$ & 73.4 & $a b$ & 12.65 & $\mathrm{ab}$ & 0.45 & $a b c$ & 0.14 & b & 3.06 & $\mathrm{cb}$ & 8.33 & $a b$ & 0.00 & $\mathrm{~b}$ & 0.10 & $\mathrm{ab}$ \\
\hline \multirow{3}{*}{21} & CSF & 20.1 & $\mathrm{~b}$ & 27.1 & $\mathrm{~b}$ & 22.8 & $\mathrm{c}$ & 106.4 & $\mathrm{e}$ & 22.8 & $\mathrm{e}$ & 16.9 & $\mathrm{c}$ & 0.11 & $\mathrm{~b}$ & 1.02 & $a b$ & 0.23 & $\mathrm{~b}$ & 1.03 & $\mathrm{c}$ & 0.94 & $\mathrm{~d}$ & 0.00 & $\mathrm{~b}$ & 0.00 & $\mathrm{e}$ \\
\hline & ASD1 & 7.6 & $\mathrm{~b}$ & 85.1 & $\mathrm{a}$ & 237.2 & $\mathrm{bc}$ & 188.0 & de & 46.4 & ed & 53.3 & $\mathrm{~b}$ & 3.74 & $a b$ & 0.18 & $\mathrm{c}$ & 0.15 & b & 2.15 & $\mathrm{cb}$ & 4.70 & bcd & 0.00 & b & 0.05 & $\mathrm{~cd}$ \\
\hline & ASD2 & 5.5 & $\mathrm{~b}$ & 89.7 & $\mathrm{a}$ & 356.5 & $a b$ & 256.8 & $\mathrm{~cd}$ & 61.4 & $\mathrm{~cd}$ & 55.3 & $\mathrm{~b}$ & 8.54 & $a b$ & 0.23 & $\mathrm{bc}$ & 0.13 & D & 1.64 & $\mathrm{c}$ & 5.71 & $\mathrm{bc}$ & 0.00 & b & 0.06 & bcd \\
\hline \multicolumn{28}{|l|}{$P$ value } \\
\hline \multirow{3}{*}{\multicolumn{2}{|c|}{$\begin{array}{l}\text { Soil treatme } \\
\text { DATA (B) } \\
A \times B\end{array}$}} & \multirow{3}{*}{\multicolumn{2}{|c|}{$\begin{array}{c}0.0001 \\
0.01 \\
0.002\end{array}$}} & \multicolumn{2}{|c|}{0.0001} & \multicolumn{2}{|c|}{0.0001} & \multicolumn{2}{|c|}{0.0001} & \multicolumn{2}{|c|}{0.0001} & \multicolumn{2}{|c|}{0.0001} & \multicolumn{2}{|c|}{0.001} & \multicolumn{2}{|c|}{0.002} & \multicolumn{2}{|c|}{0.0001} & 0.000 & & 0.00 & & 0.6 & & 0.00 & \\
\hline & & & & 0.000 & & 0.00 & & 0.000 & & 0.006 & & 0.00 & & 0.36 & & 0.6 & & 0.000 & & 0.000 & & 0.00 & & 0.06 & & 0.00 & 01 \\
\hline & & & & 0.0 & & 0.0 & & 0.1 & & 0.0 & & 0.0 & & 0.1 & & 0.0 & & 0.000 & & 0.000 & & 0.1 & & 0.03 & & & \\
\hline
\end{tabular}

685

$686{ }^{\mathrm{z}}$ Reported values are averages of four replications. Means followed by different letters within each column and location are significantly different

687 at $\alpha=0.05$ by Duncan's multiple range test. ${ }^{\mathrm{y}}$ DATA (days after treatment application). ${ }^{\mathrm{x}} \mathrm{CSF}$ (chemical soil fumigation), ASD1 (anaerobic soil

688 disinfestation with $13.9 \mathrm{~m}^{3} \mathrm{ha}^{-1}$ of molasses), ASD2 (anaerobic soil disinfestation with $27.7 \mathrm{~m}^{3} \mathrm{ha}^{-1}$ of molasses). 

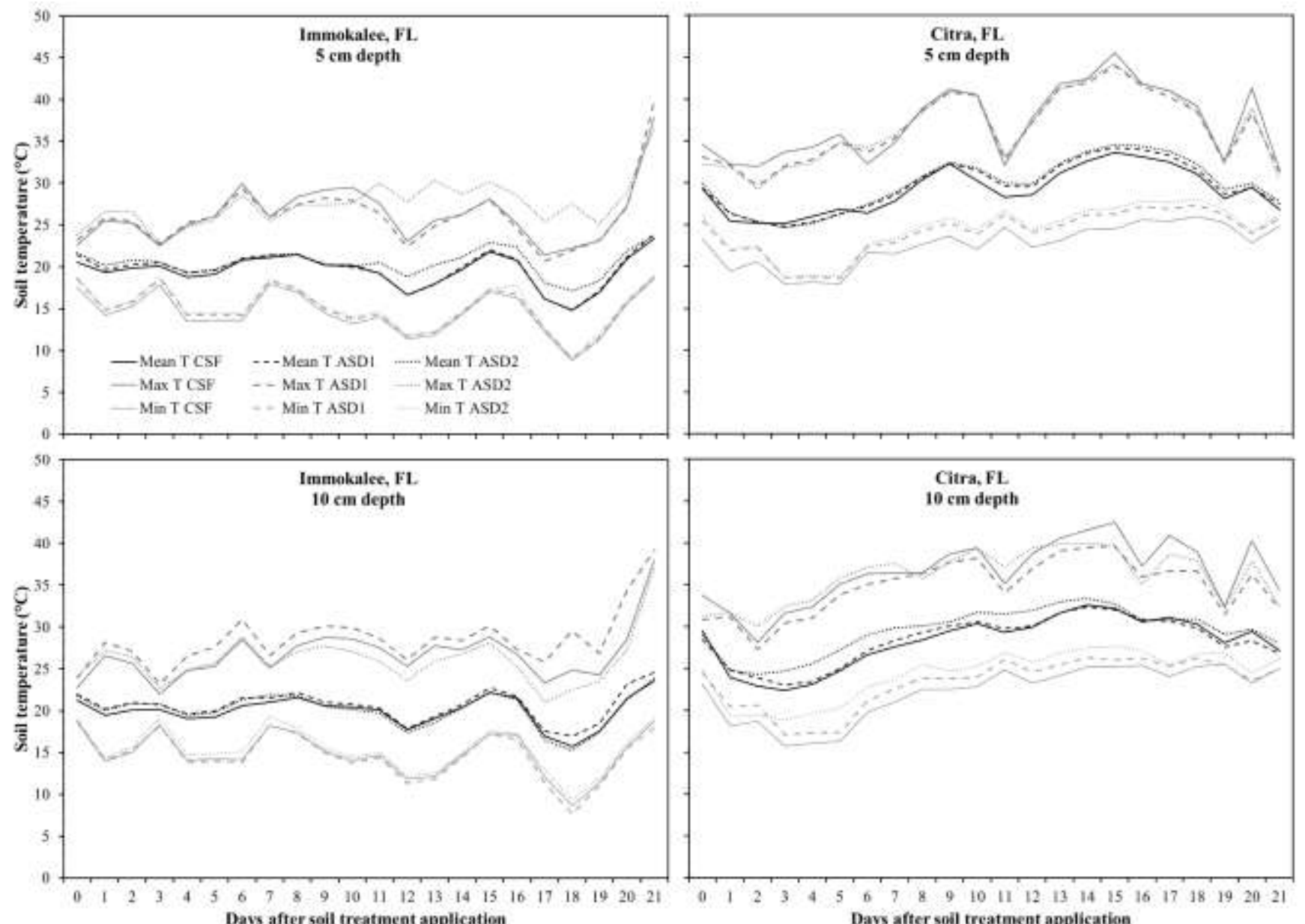

690 Figure 1. Mean, maximum, and minimum soil temperature recorded at 5 and $10 \mathrm{~cm}$ depth, as affected by soil treatments in Immokalee and Citra

691 during the spring of 2015. CSF (chemical soil fumigation, with Pic-Clor 60 at the rate of $224 \mathrm{~kg} \mathrm{ha}^{-1}$ in Immokalee, and Paladin ${ }^{\mathrm{TM}}$ at the rate of

$692496 \mathrm{~L} \mathrm{ha}^{-1}$ in Citra); ASD1 (anaerobic soil disinfestation with $13.9 \mathrm{~m}^{3} \mathrm{ha}^{-1}$ of molasses, and $22 \mathrm{Mg}^{-1} \mathrm{of}^{-1}$ composted poultry litter); ASD2

693 (anaerobic soil disinfestation with $27.7 \mathrm{~m}^{3} \mathrm{ha}^{-1}$ of molasses, and $22 \mathrm{Mg} \mathrm{ha}^{-1}$ of composted poultry litter). 

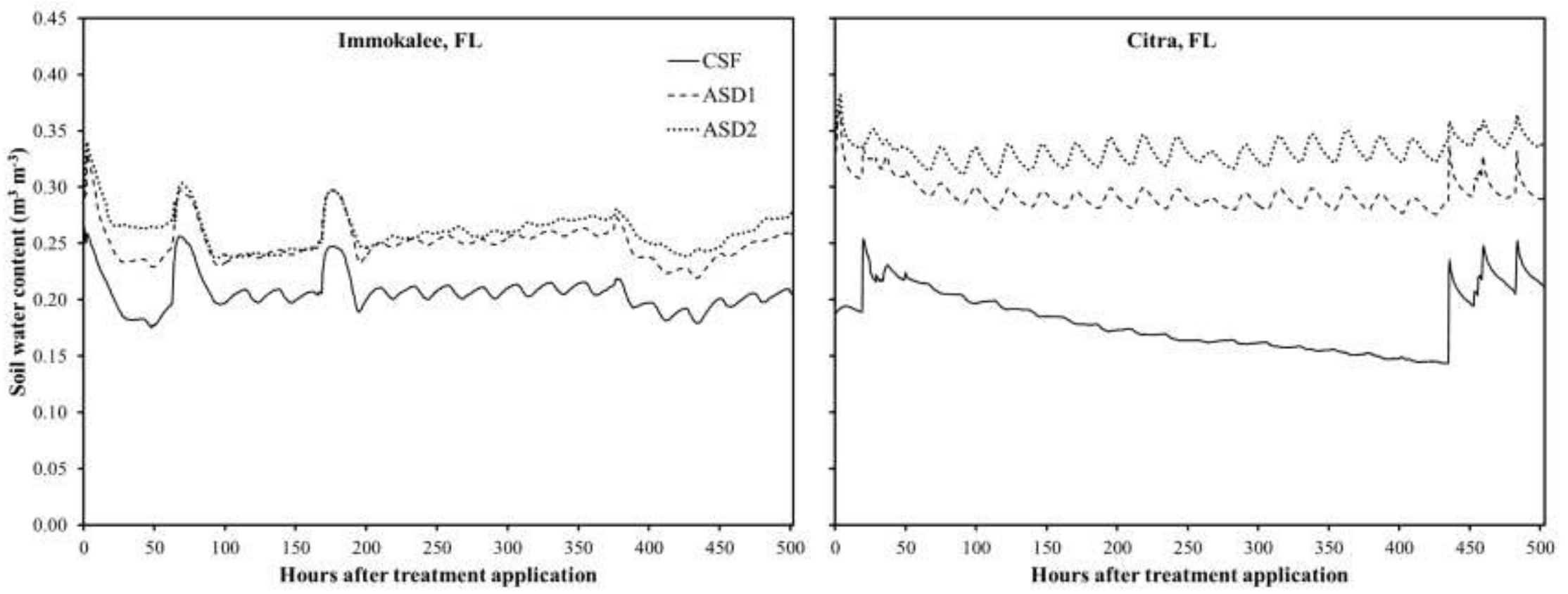

695 Figure 2. Volumetric soil water content, measured at $10 \mathrm{~cm}$ depth, as affected by soil treatments in Immokalee and Citra, in the spring of 2015.

696 CSF (chemical soil fumigation, with Pic-Clor 60 at the rate of $224 \mathrm{~kg} \mathrm{ha}^{-1}$ in Immokalee, and Paladin ${ }^{\mathrm{TM}}$ at the rate of $496 \mathrm{~L}^{-1} \mathrm{in} \mathrm{Citra)}$; ASD1

697 (anaerobic soil disinfestation with $13.9 \mathrm{~m}^{3} \mathrm{ha}^{-1}$ of molasses, and $22 \mathrm{Mg} \mathrm{ha}^{-1}$ of composted poultry litter); ASD2 (anaerobic soil disinfestation with

$69827.7 \mathrm{~m}^{3} \mathrm{ha}^{-1}$ of molasses, and $22 \mathrm{Mg} \mathrm{ha}^{-1}$ of composted poultry litter).

699

700

701 

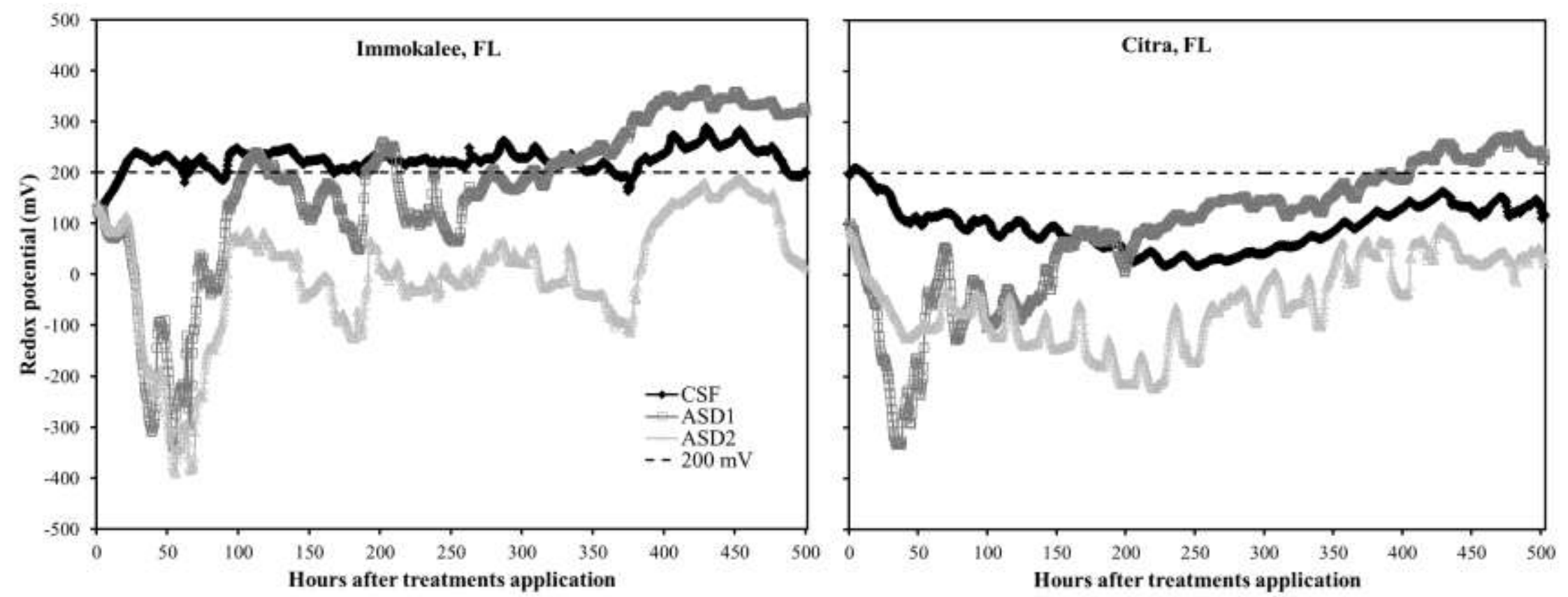

Figure 3. Mean hourly soil redox potential (Eh) as affected by soil treatments in Immokalee and Citra, in the spring of 2015. CSF (chemical soil molasses, and $22 \mathrm{Mg} \mathrm{ha}^{-1}$ of composted poultry litter). 

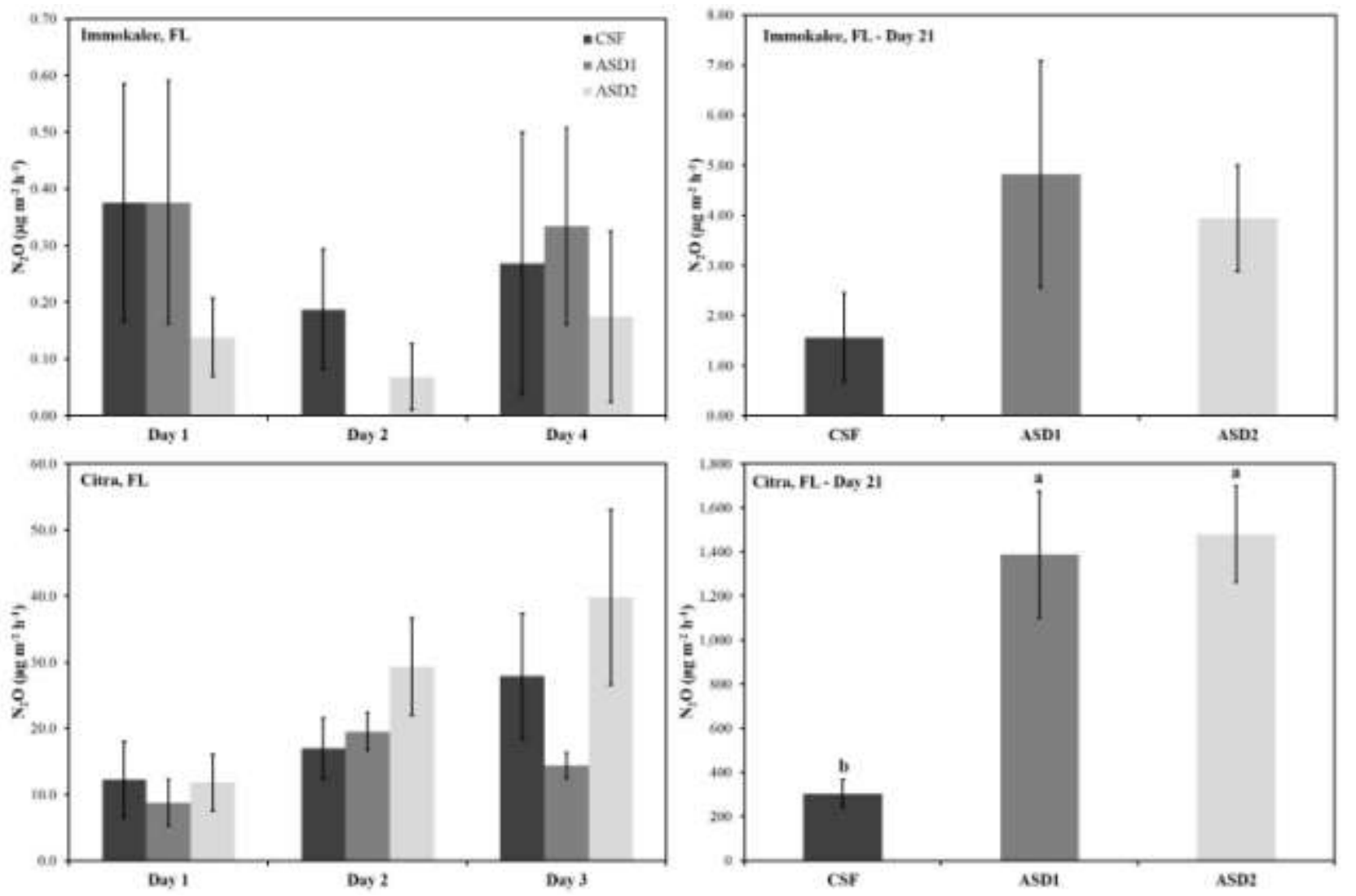

708 Figure 4. Soil treatment effects on $\mathrm{N}_{2} \mathrm{O}$ flux $\left(\mu \mathrm{g} \mathrm{m}^{-2} \mathrm{~h}^{-1}\right)$ measured on top of beds mulched with totally impermenable film (1, 2, 3 or 4 days after

709 treatment application) and after punching the mulching film (21 days after treatment application) in Immokalee and Citra, in the spring of 2015.

$710 \mathrm{CSF}$ (chemical soil fumigation, with Pic-Clor 60 at the rate of $224 \mathrm{~kg} \mathrm{ha}^{-1}$ in Immokalee, and Paladin ${ }^{\mathrm{TM}}$ at the rate of $496 \mathrm{~L} \mathrm{ha}^{-1}$ in Citra); ASD1

711 (anaerobic soil disinfestation with $13.9 \mathrm{~m}^{3} \mathrm{ha}^{-1}$ of molasses, and $22 \mathrm{Mg} \mathrm{ha}^{-1}$ of composted poultry litter); ASD2 (anaerobic soil disinfestation with

$71227.7 \mathrm{~m}^{3} \mathrm{ha}^{-1}$ of molasses, and $22 \mathrm{Mg} \mathrm{ha}^{-1}$ of composted poultry litter). Reported values are averages of four replications. Means followed by

713 different letters are significantly different at $\alpha=0.05$ by Duncan's multiple range test. 